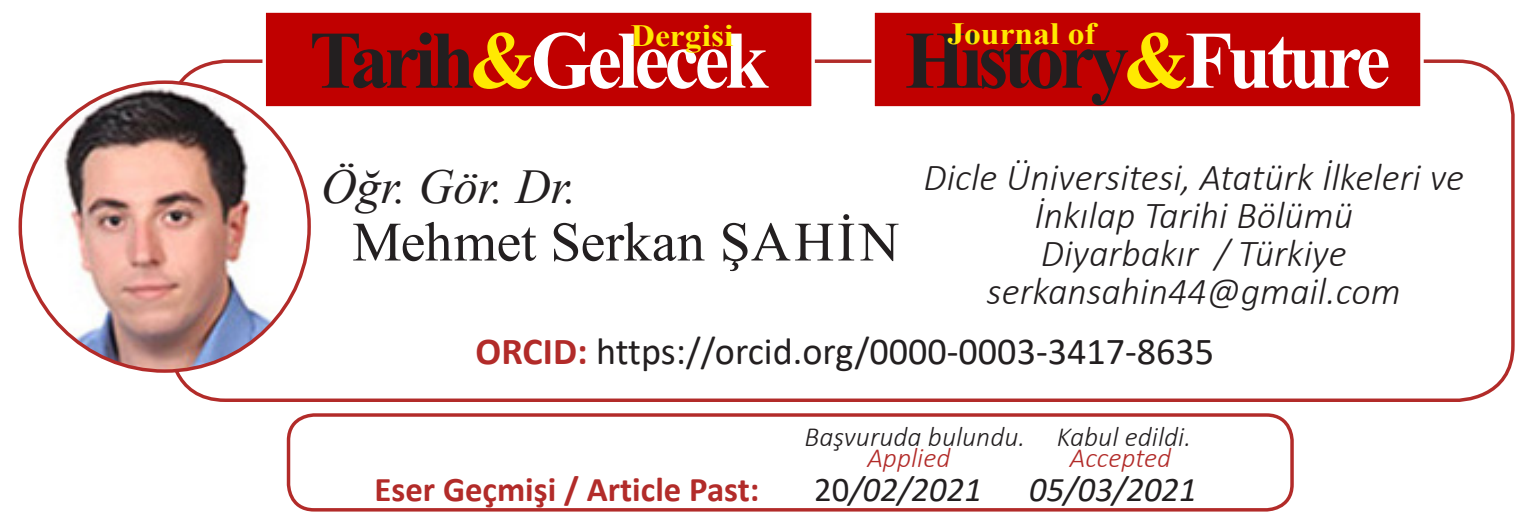

Araştırma Makalesi

DOI: http://dx.doi.org/10.21551/jhf.884017

Research Paper

Orjinal Makale / Orginal Paper

\title{
Türkiye Büyük Millet Meclisi'nde 27 Y1l Malatya Milletvekili Mahmut Nedim ZABCI (1923-1950)
}

\author{
27 Years in The Grand National Assembly of Turkey Mahmut Nedim ZABCI \\ Deputy of Malatya (1923-1950)
}

\section{Öz}

Malatya milletvekili Mahmut Nedim Zabcı 1923 yılında açılan ikinci dönem meclisine katılarak parlamento hayatına başladı. Türk inkılap tarihine yön veren önemli kararların alındığı bu meclis döneminde aktif olarak görev yaptı. Saat sisteminin değişimini öngören ve günü yirmi dört saate bölen tasarıyı hazırlayan komisyonun sözcülüğünü üstlendi. 1927, 1931, 1935, 1939, 1943 ve 1946 seçimlerinde de CHP tarafından aday gösterildi ve milletvekili seçildi. Böylece aralıksız yirmi yedi sene Malatya milletvekili olarak TBMM'de yer aldı. Bu uzun parlamento hayatında gerek ülke sorunları gerekse Malatya'nın ihtiyaçlarını gündeme getirerek çözüm yolları aradı. Bu çalışma Malatya milletvekili Mahmut Nedim Zabcı'nın TBMM bünyesinde yirmi yedi yıl süren parlamento hayatını konu almaktadır. Çalışmada Zabcı'nın genel kurul konuşmaları ile birlikte başkanlık divanına sunduğu önerge ve kanun teklifleri ele alınacak ve böylece Mahmut Nedim Bey'in yasama faaliyetleri geniş bir şekilde incelenmeye çalışılacaktır.

\section{Anahtar Kelimeler: TBMM, Mahmut Nedim Zabc1, Malatya, Tek Parti Dönemi}

\section{Abstract}

Malatya deputy Mahmut Nedim Zabc1 joined the second term parliament, which was opened in 1923, and started his parliamentary life. He actively served during this parliamentary period, when important decisions were taken that shaped the history of Turkish revolution. He was the spokesperson of the commission that prepared the bill envisaging the change of the clock system and dividing the day into twenty four hours. He was nominated and elected by the CHP in the elections of 1927, 1931, 1935, 1939, 1943 and 1946. Thus, he took part in TBMM as a Malatya deputy for twenty seven years. In this

\footnotetext{
* Bu makale tarafimdan hazırlanan ve Kahramanmaraş Sütçü Imam Üniversitesi Sosyal Bilimler Enstitüsü'nün 2016 yılında kabul ettiği "Türkiye Büyük Millet Meclisi'nde Malatya Milletvekilleri ve Siyasi Faaliyetleri (1923-1950)" başlıklı doktora tezinden üretilmiştir.
} 
long parliamentary life, he sought solutions by bringing the problems of the country and the needs of Malatya to the agenda. This study focuses on the parliamentary life of Malatya Deputy Mahmut Nedim Zabc1, which lasted for twenty seven years within the body of the Turkish Grand National Assembly. In the study, the proposals and bills submitted by Zabci to the presidential council together with the speeches of the general assembly will be discussed, and thus, the legislative activities of Mahmut Nedim Bey will be examined extensively.

Keywords: Grand National Assembly of Turkey, Mahmut Nedim Zabc1, Malatya, OneParty Period.

\section{Giriş}

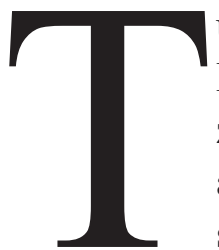

ürkiye Büyük Millet Meclisi 23 Nisan 1920 günü Ankara'da açıldı. Birinci Dünya Savaşı sonrası işgal edilen Anadolu'nun bağımsızlık mücadelesini zaferle sonuçlandıran bu gazi meclis 1923 yılında seçimleri yenileme kararı aldı. Yenilenen TBMM ise önce Lozan Barış Antlaşması'nı onayladı ve sonrasında Cumhuriyet rejimini kabul ederek Türkiye tarihinde yeni bir dönem açtı. Böylece TBMM yenilenen seçimler ile birlikte devletin temel yapılarını inşa etme sürecine başladı. Takip eden yıllarda da meclis dört yıl arayla yapılan seçimler sonucunda yenilendi. Erken Cumhuriyet dönemi seçimleri sonucunda Malatya'dan parlamentoya seçilen milletvekilleri şu isimlerden oluştu:

İkinci dönem TBMM seçimleri (1923): İsmet İnönü, Mahmut Nedim Zabcı, Reşit Ağar, Hac1 Bedir Firat, Hilmi Oytaç

Üçüncü dönem TBMM seçimleri (1927): İsmet İnönü, Mahmut Nedim Zabcı, Vasıf Çınay, Fazıl Berki Tümtürk, Hilmi Oytaç, Abdülmuttalip Öker

Dördüncü dönem TBMM seçimleri (1931): İsmet İnönü, Mahmut Nedim Zabcı, Vasıf Çınay, Talat Haşim Ural, Hilmi Oytaç, Abdülmuttalip Öker

Beşinci dönem TBMM seçimleri (1935): İsmet İnönü, Mahmut Nedim Zabc1, Osman Nuri Koptagel, Vasıf Çınay, Mihri Pektaş, Hilmi Oytaç, Abdülmuttalip Öker, Emrullah Barkan, Osman Hilmi Taner

Altıncı dönem TBMM seçimleri (1939): Mahmut Nedim Zabcı, Osman Nuri Koptagel, Vasıf Çınay, Mihri Pektaş, Hilmi Oytaç, Abdülmuttalip Öker, Emrullah Barkan, Osman Hilmi Taner, Nasuhi Baydar, Memet Şevket Özpazarbaşı

Yedinci dönem TBMM seçimleri (1943): Mahmut Nedim Zabc1, Mihri Pektaş, Abdülmuttalip Öker, Emrullah Barkan, Osman Hilmi Taner, Nasuhi Baydar, Memet Şevket Özpazarbaşı, Kemal Sayın, Halet Sağıroğlu, Cafer Özelçi, Tevfik Temelli

Sekizinci dönem TBMM seçimleri (1946): Mahmut Nedim Zabcı, Mehmet Sadık Eti, Hikmet Fırat, Emrullah Barkan, Osman Hilmi Taner, Mustafa Naim Karaköylü, Cafer Özelçi, Tevfik Temelli, Şefik Tugay, Atıf Esenbel, Abdülkadir Taşangil, Abdurrahim Ulvi Beydağ $1^{1}$

1 Mehmet Serkan Şahin, Türkiye Büyük Millet Meclisi’nde Malatya Milletvekilleri ve Siyasi Faaliyetleri (1923-1950), Kahramanmaraş Sütçü İmam Üniversitesi Sosyal Bilimler Enstitüsü, (Yayınlanmamış Doktora Tezi), Kahramanmaraş, 2016, s. 25-47. 


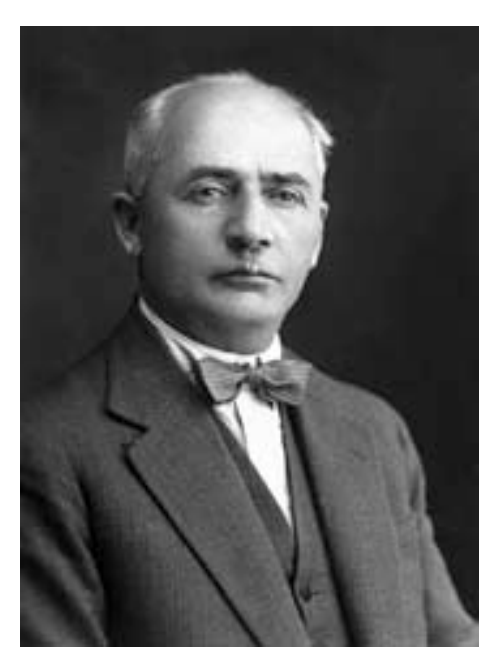

Mahmut Nedim ZABCI

(Kaynak: https://tbmm.chp.org.tr/milletvekiliDetay.aspx?ID=3293)

\section{Mahmut Nedim Zabcı'nın Siyasi Biyografisi}

1882 yılında Malatya'da doğan Mahmut Nedim Zabcı ilk ve orta eğitimi Malatya'da tamamladıktan sonra Harput Askeri Rüştiyesi ve Erzurum Askeri İdadisi'ni bitirdi. ${ }^{2} 1902$ y1lında Harp Okulu'na girdi ve 1906'da Teğmen, 1907'de Üsteğmen, 1909'da Yüzbaş1, 1914'te Binbaş1 ve 1921 'de Yarbay rütbelerini ald1. ${ }^{3}$

II. Meşrutiyet'in ilanından sonra İttihat ve Terakki Cemiyeti'ne katıldı ancak subayların siyasetle uğraşmasının yasaklanması üzerine cemiyetten ayrıldı. 1911 yılında Haritacılık eğitimi almak üzere Fransa'ya gitti. ${ }^{4}$ Trablusgarp Savaşı'na katıld1. ${ }^{5}$ Balkan Savaşları'nda Selimiye Fırkası, Kasımpaşa ve 4. Gönüllü taburlarında görev yaptı. ${ }^{6}$ Birinci Dünya Savaşı'nda Kafkas cephesinde Sarıkamış harekâtına katıldı. II. İnönü Savaşı sonrasında Milli Mücadele’ye katılarak Harita Dairesi'nde görev yaptı ve İstiklâl Savaşı'ndaki hizmetlerinden dolayı Kırmızı Şeritli İstiklâl Madalyası ald $1 .^{7}$

TBMM ikinci dönem seçimlerinde Malatya'dan aday gösterilen Zabcı 23 Temmuz 1923 günü yapılan seçimlerde 450 oy alarak Malatya milletvekili seçildi. Aldığı oyların ilçelere göre dağılımı şöyle idi: ${ }^{8}$ Malatya merkez 101, Besni 95, Adıyaman 70, Kâhta 40, Akçadağ 45, Pütürge

2 Kazım Öztürk, Türk Parlamento Tarihi (TBMM II. Dönem 1923-1927), C. 3, TBMM Vakfı Yayınları, Ankara, 1995, s. 587.

3 Emekli Sandı̆̆ı Genel Müdürlüğ̈̈ Arşivi (ESA), Dosya No A0109668.

4 Öztürk, Türk Parlamento Tarihi (TBMM II. Dönem 1923-1927), C. 3, s. 587-588.

5 T.C. Cumhurbaşkanlı̆̆ Devlet Arşivleri Başkanlı̆̆l Cumhuriyet Arşivi (BCA), 490.01/312.1274.1

6 ESA, A0109668.

7 Öztürk, Türk Parlamento Tarihi (TBMM II. Dönem 1923-1927), C. 3, s. 588.

8 Erken Cumhuriyet yıllarında Malatya'nın idari taksimatına yönelik düzenlemeler nedeniyle vilayete bağl1 ilçeler değişkenlik gösterdi. Örneğin seçim sonuçlarında da görüldüğü gibi Besni ikinci dönem seçimlerinin yapıldığ 1923 yılı itibarıyla Malatya'ya bağlı iken, üçüncü dönem seçimlerinin yapıldığ1 
62, Hekimhan $37 .^{9}$

Üçüncü dönem TBMM seçimlerinde de Malatya'dan aday olan Zabcı aldığ́ 498 oyla tekrar milletvekili seçildi. Oyların seçim bölgelerine göre dağılımı ise şöyle oldu: Malatya merkez 119, Arapgir 57, Adıyaman 108, Pütürge 26, Akçadağ 53, Hekimhan 55, Kâhta 27 ve Kemaliye 53. ${ }^{10}$

Mahmut Nedim Zabcı TBMM dördüncü dönem seçimlerinde yine Malatya milletvekili seçilirken bu defa 584 oy aldı. Bu oyların ilçelere göre dağılımı ise şöyle idi: Malatya merkez 136, Adıyaman 118, Kâhta 42, Pütürge 61, Hekimhan 69, Akçadağ 54, Arapgir 62, Kemaliye $42 .{ }^{11}$

TBMM beşinci dönem seçimlerinde yeniden Malatya milletvekili seçilen Zabcı 8 Şubat 1935 Cuma günü yapılan seçimlerde 785 oy aldı. Oyların dağılımı şu şekilde oldu: Malatya merkez 134, Adiyaman 129, Kâhta 65, Pütürge 45, Hekimhan 68, Akçadă̆ 85, Arapgir 70, Kemaliye 39, Darende 63, Besni 87. ${ }^{12}$

Mahmut Nedim Zabcı TBMM altıncı dönem seçimlerinde 939 oyla Malatya milletvekili seçilirken, oyların dağılımı Malatya merkez 213, Adıyaman 145, Kâhta 75, Pütürge 90, Hekimhan 83, Akçadağ 87, Arapgir 74, Darende 67, Besni 105 şeklinde idi. ${ }^{13}$

TBMM yedinci dönem seçimlerinde Mahmut Nedim Zabcı altıncı defa Malatya milletvekilliğine seçildi. Aldığı 952 oyun dağılımı ise şöyle idi: Malatya merkez 213, Adıyaman 146, Kâhta 65, Pütürge 106, Hekimhan 81, Akçadağ 107, Arapgir 74, Darende 41, Besni 119. ${ }^{14}$

TBMM sekizinci dönem seçimlerinde yedinci ve son defa CHP listesinden Malatya milletvekilliğine seçilen Zabcı 94.495 oy aldı. Bu oyların ilçelere göre dağılımı şu şekilde idi: Malatya merkez 20.689, Adıyaman 8.508, Kâhta 5.144, Pütürge 20.405, Hekimhan 2.511, Akçadăg 8.986, Arapgir 6.781, Darende 6.107, Besni 8.382, Doğanşehir 6.982. ${ }^{15}$

Mahmut Nedim Zabcı parlamentoda Malatya milletvekili olarak yedi dönem görev yaptı ve 27 y1l boyunca bu görevini sürdürdü. Dokuzuncu dönem parlamento seçimlerinde de CHP'ye Malatya milletvekili adaylığı başvurusu yaptı fakat yapılan yoklama sonucunda listeye giremedi.

Milletvekilliği döneminde Malatya’da Teşebbüsat-1 Sınaiye Şirketi, Okumuşu Çoğaltma ve Okuyanı Koruma Cemiyeti, Kadınlar Birliği, Çiftçiler Birliği gibi oluşumların kuruluşlarında büyük pay sahibi olan Mahmut Nedim Zabcı ayrıca Eski Muharipler Bankası İdare Meclisi Başkanlığı, Türk Hava Kurumu Murakıplığı ve Harp Malûlleri Birliği Başkanlığı görevlerinde bulundu ve Türk Dil Kurumu derleme bölümünde görev yapt $1^{16}$

1927'de Gaziantep'e bağlıdır. Beşinci dönem seçimlerinin yapıldığı 1935 yılına gelindiğinde ise söz konusu ilçe tekrar Malatya vilayeti içerisinde yer almaktadır. Benzer değişiklikler Arapgir ve Kemaliye için de yaşanacaktır.

9 Türkiye Büyük Millet Meclisi Arşivi, Sicil No 584.

10 TBMM Arşivi, 584.

11 TBMM Arşivi, 584.

12 TBMM Arşivi, 584.

13 TBMM Arşivi, 584.

14 TBMM Arşivi, 584.

15 TBMM Arşivi, 584.

$16 \quad B C A, 490.01 / 312.1274 .1 ; B C A, 490.01 / 374.1576 .2 ; B C A, 490.01 / 235.929 .4$ 
Fransızca ve Almanca bilen Zabcı evli ve dört çocuk sahibi idi. 8 Şubat 1955 günü İstanbul'da vefat etti.

\section{2. İkinci Meclis Dönemi Faaliyetleri (1923-1927)}

İkinci dönem TBMM Türk inkılâp tarihinin en önemli kararlarının alındığı parlamento oldu. Lozan Barış Antlaşması'nın kabul edilmesi, Ankara'nın başkent olması, Cumhuriyetin ilanı, Hilafetin kaldırılması ve rejimin laikleştirilmesi başta olmak üzere çok önemli kararlar alan bu meclis aynı zamanda cumhuriyetin ilk anayasasını da hazırlayıp yürürlüğe koydu. 20 Nisan 1924 tarihinde kabul edilen Teşkilat-1 Esasiye Kanunu'na göre seçimler dört yılda bir yapılacaktı. Her milletvekili yalnız kendini seçen bölgenin değil tüm milletin vekili olacak ve meclis her yıl Kasım ayı başında çağrı yapılmaksızın toplanacaktı. ${ }^{17}$

TBMM ikinci dönem yasama süreci içerisinde Cumhuriyet tarihinin ilk muhalefet partisi de doğdu. Halk Fırkası'ndan ayrılan bir grup milletvekili tarafindan 17 Kasım 1924 tarihinde kurulan Terakkiperver Cumhuriyet Fırkası'nın genel başkanı Kâzım Karabekir'di. Ancak çok partili yaşam uzun ömürlü olmadı ve Şeyh Sait İsyanı sürecinde irticayı körüklemekle itham edilen parti 5 Haziran 1925 tarihinde kapatıld1. ${ }^{18}$ Bu gelişmenin ardından Türkiye uzun bir tek parti rejimine girdi. CHP'nin kurduğu bu tek parti rejiminde TBMM toplumun yapısını yansıtmaktan ziyade CHP'nin toplumsal bileşimini yansıtmaya başladı. 1924 Anayasası meclise diğer siyasal organlar karşısında açık bir üstünlük tanımasına rağmen tek parti rejimi bunu tersine çevirdi ve TBMM CHP hükümetlerinin danışma organı haline gelerek parti kararlarını meşrulaştırma işlevi gördü. ${ }^{19}$

Mahmut Nedim Zabcı TBMM'de görev aldığı bu ilk dönemde Nafia ve Umur-1 Tasarrufiye komisyonlarında görev yaptı. ${ }^{20}$ Dönem boyunca Meclis Başkanlığı'na sunduğu önergeler şunlar oldu.

Malatya milletvekili Mahmut Nedim Bey TBMM'nin 21 Kasım 1923 tarihli oturumunda Suriye müvaridatına karşı mamul şeker tarifesinin tatbiki ile Malatya - Gaziantep tarikinin tesrii inşası temenniyatına dair önerge ile Malatya 'nın tütün zerriyatı mıntıkasına ithali ve Rumeli'den gelecek muhacirinden icabı kadar tütün müstahsıllarının mahallî mezkûrda iskânı temenniyatına dair önergeyi verdi ve bu önergeler Başvekâlet'e havale edildi. ${ }^{21}$

Mahmut Nedim Bey bazı milletvekili arkadaşları ile birlikte 6 Şubat 1924 tarihli oturumda Malatya'da Fabrikatör Mehmet Efendi'nin²2 Teşvik-i Sanayi Kanunu ahkâm-ı mahsusasına

17 Suna Kili / Şeref Gözübüyük, Sened-i İttifak'tan Günümüze Türk Anayasa Metinleri, Türkiye İş Bankas1 Kültür Yayınları, İstanbul, 2006, s. 128-133.

18 Tarık Zafer Tunaya, Türkiye'de Siyasi Partiler 1859-1952, İstanbul, 1952, s. 606-614; Ömür Sezgin / Gencay Şaylan, "Terakkiperver Cumhuriyet Fırkası”, Cumhuriyet Dönemi Türkiye Ansiklopedisi, C. 8, s. 2043-2051.

19 Esat Öz, Otoriterizm ve Siyaset Türkiye'de Tek-Parti Rejimi ve Siyasal Katılma (1923-1945), Yetkin Yayınları, Ankara, 1996, s. 140-141.

20 Türkiye Büyük Millet Meclisi Zabıt Ceridesi (TBMM ZC), Devre II - C. 1, s. 73.

21 TBMM ZC, D. II - C. 3, ss. 495-496.

22 TBMM Zabıt Ceridesi’nde Fabrikatör Ömer Efendi olarak geçmektedir. Ancak Cumhuriyet Arşivi’nde yer alan önerge metninde Fabrikatör Mehmet Efendi şeklindedir. Döneme ait literatür incelendiğinde Fabrikatör Mehmet Efendi olduğu görülmektedir. Bkz. Celal Pekdoğan, Milli Mücadelede Malatya ve Çevresi (Demografik, İdarî, Siyasi ve Sosyo-Ekonomik Açıdan) 1918-1922, Hacettepe Üniversitesi Atatürk İlkeleri ve İnkılâp Tarihi Enstitüsü (Yayınlanmamış Yüksek Lisans Tezi), Ankara, 1992. 
tevfikan himayesine dair bir önerge verdi. ${ }^{23} \mathrm{Bu}$ önerge Başvekâlet'e sevk edildi. ${ }^{24}$

Mahmut Nedim Bey'in Malatya vilayetine bir kurutma makinesi ile bir ispirto makinesi gönderilmesine dair önergesi ${ }^{25}$ meclisin 17 Şubat 1924 tarihli oturumunda Başvekâlet'e havale edildi. ${ }^{26}$

Konya milletvekili Kâzım Hüsnü Bey ve arkadaşlarının 24 Mart 1924 tarihinde Meclis Başkanlı̆̆ı'na sundukları önergede Malatya milletvekili Mahmut Nedim Bey'in de imzası vardı. Konya'nın Karaman ilçesine su götürülebilmesi için Maliye Vekâleti bütçesine 15.000 lira ilave edilmesine dair önergede Karaman'da temiz su bulunmadığından dolayı ortaya çıkan hastalıklardan her sene binlerce kişinin hastalandığı belirtilmekte ve bunu önlemek için halkın çevredeki temiz su göletlerinden demir borularla ilçeye su getirmeye çabaladığı ancak yüksek masraftan dolayı bunun mümkün olmadığı vurgulanıyordu. Bu projenin tamamlanabilmesi için bütçeye gerekli miktarın ilavesi isteniyordu. Genel kurulda yapılan oylamada önerge kabul edildi. ${ }^{27}$

1924 yılı Ticaret Vekâleti bütçesi kanunu müzakerelerinin yapıldığı 1 Nisan 1924 tarihli oturumda aralarında Mahmut Nedim Bey'in de bulunduğu bazı milletvekilleri tarafından kaleme alınan önergede Milli Mücadele yıllarında Yunan ordusu tarafından tahrip edilen Karamürsel Şayak Fabrikası'nın üç seneden beri kapalı olduğu ve bu nedenle yüzlerce iş̧̧inin işsiz kaldığı belirtilmekte ve bu fabrikanın onarılıp yeniden üretime geçebilir hale getirilmesini sağlamak için teşvik-i sanayi kaleminden 50.000 lira verilmesi teklif edilmekteydi. Aynı oturumda Mahmut Nedim Bey seçim bölgesi Malatya ile ilgili -50 milletvekilinin desteğini alarak- bir önerge de verdi. Söz konusu önergede Mehmet Efendi adlı girişimcinin otuz sene evvel Malatya'da tekstil fabrikası kurarak beş yüz işçi istihdam ettiği, Birinci Dünya Savaşı'nda doğu ve güney ordularının ihtiyaçlarını karşıladığı, Milli Mücadele'ye de elindeki son sermaye ile katkı sağladığı ve sonrasında yaşadığı ekonomik sıkıntılar nedeniyle fabrikasını kapatmak zorunda kaldığı belirtiliyordu. Fabrikatör Mehmet Efendi'nin otuz bin lira alacağına karşlık hükümetten yalnızca beş bin lira tahsil edebildiğinin vurgulandığı önergede fabrikasını tekrar açabilmesi için bütçeden adı geçen girişimciye yirmi bin lira ödenek ayrılması talep ediliyordu. ${ }^{28}$ Her iki önerge de genel kurulda oylanarak reddedildi. ${ }^{29}$

TBMM'nin 22/23 Nisan 1924 tarihli kapalı oturumunda (gizli celse) Lozan Barış Antlaşması gereğince ilan edilen genel af kapsamı dışında tutulacak 150 kişilik liste müzakere edildi. Uzun tartışmaların yaşandığı görüşmelerde birçok milletvekili listeye yeni isimlerin eklenmesini talep ettiler. Bu milletvekillerinden biri olan Mahmut Nedim Bey TBMM Başkanlı̆̆ı'na şu önergeyi verdi: "Muhip Mağmumî isminde ziraat mühendisi bir melun vardır. Büyük milletimizin ebedî düssmanıdır. Macaristan'da hlyanetine devam etmektedir. Milletime hakaretinden dolayı kâfire o kadar hıncım vardır ki elime geçse diş̧lerimle parçalayacağım. Melunun mutlaka listeye ithalini Heyet-i Celile'den rica ederim"

$\begin{array}{ll}23 & B C A, 30.10 / 6.36 .15 \\ 24 & T B M M Z C, \text { D. II - C. } 5, \text { s. } 606 . \\ 25 & B C A, 30.10 / 6.36 .27 \\ 26 & T B M M Z C, \text { D. II - C. } 6, \text { s. } 46 . \\ 27 & T B M M Z C, \text { D. II - C. } 7 / 1, \text { s. } 1024-1026 . \\ 28 & B C A, 30.10 / 6.36 .15 \\ 29 & T B M M Z C, \text { D. II - C. } 8, \text { s. } 193-195,197 .\end{array}$


Genel kurul, Dahiliye Vekili Ahmet Ferit (Tek) Bey'in talebi doğrultusunda mevcut listeye sadece üç kişinin eklenmesi kararını alınca Mahmut Nedim Bey’in önergesi dikkate alınmadı. ${ }^{30}$

Tekfurdağı (Tekirdağ) milletvekili Cemil Bey’in öncülüğünde hazırlanan ve aralarında Malatya milletvekili Mahmut Nedim Bey'in de bulunduğu 100 milletvekilinin imzası ile sunulan Meclis memurin ve müstahdeminine maatahsisat birer maaş nispetinde ikramiye itasına dair önerge meclisin 29 Aralık 1924 tarihli oturumunda gündeme alındı. Maaşlarına zam yapılmayan ve kışın sert geçmesi nedeniyle sıkıntı içinde olan meclis memurlarına bir maaş ikramiye verilmesinin teklif edildiği önerge TBMM İdare Heyeti tarafından olumlu bulunarak kanun teklifine dönüştürüldü ve Muvazene-i Maliye Encümeni’ne havale edildi. ${ }^{31}$ Söz konusu komisyonun hazırladığı mazbata 31 Aralık 1924 tarihli oturumda kabul edildi. ${ }^{32}$

Malatya milletvekili Mahmut Nedim Bey’in seçim bölgesi ile ilgili verdiği Sultansuyu Çiftliği’nin numune Ziraat Mektebi ve numune çiftliği halinde işletilmesi hakkındaki önerge ${ }^{33}$ meclisin 12 Ocak 1925 tarihli oturumunda Başvekâlete havale edildi. ${ }^{34}$

Meclisin 11 Şubat 1925 tarihli oturumunda gündeme alınan 1925 yılı Maliye Vekâleti bütçesi görüşmelerinde Mahmut Nedim Bey seçim bölgesi ile ilgili olarak verdiği önergede şu talepte bulundu: "Malatya derununda cereyan eden dermih (Derme) suyu, akar su pislik götürmez diye telvis edilmektedir. Verilen müteaddit sihhi raporla bu suyun katiyyen gayri kabili şurp olduğunu ispat etmişken ahalinin hâlâ bu suyu her türlü ihtiyaçlarında kullanmaları bütün şehir sekenesinin ahvali sihhiyesini, hayatını zehirlemiştir. Tifo, Verem, Dizanteri, münteşir bir haldedir. Sihhiye Vekâleti'nin tanzim ettiği istatistik nazar ibretle tetkik edilirse Türkiye vilâyetleri içinde en ziyade vefiyat veren ve bu hal ile mahvolması muhakkak olan Malatya şehri Meclis-i Ali'nin nazarı merhamet ve insafinı celbeder. Ve umumî bir surette nazarı mülâhazaya alınmasını ve buna bir çare bulunmasını arz ve teklif eylerim." Meclis Başkanı Kâzım Paşa tek imzalı olan bu önergeyi oylamaya sunamayacağını belirtti. ${ }^{35}$

Şeyh Sait İsyanı'nın yaşandı̆̆ı günlerde ülkenin dört bir yanından TBMM'ye gönderilen bağlılık telgraflarından biri Malatya'nın Besni kazasından geldi. Cumhuriyet Halk Fırkası Besni Kaza İdare Heyeti Reisi Hasan Kemal Bey'den gelen bu telgrafı Mahmut Nedim Bey bir önerge ile başkanlığa sunarak genel kurula duyurulmasını istedi. 26 Şubat 1925 tarihli oturumda genel kurulda okunan telgrafta "Muhit ve mıntıkamıza hiç bir hain fikrin hiç bir alçak elin giremeyeceğini halk ve aşairin ittihat ve tesanüdünden Hükümet-i Cumhuriyemizin tamamen emin olacağını söyler ve ledelhace bütün mevcudiyetimizle usatın tenkiline ve Hükümetin emrine amade bulunduğumuzu halk ve memleket namina arz eylerim" deniliyordu. ${ }^{36}$

Meclisin 7 Mart 1925 tarihli oturumunda gündeme alınan 1925 yılı Maarif Vekâleti bütçesi müzakerelerinde Mahmut Nedim Bey’in de aralarında bulunduğu 90 milletvekilinin imzası ile verilen bir önergede Hakkâri, Muş, Siirt, Şarki Karahisar, Mardin, Diyarbakır, Elazı̆̆g, Malatya,

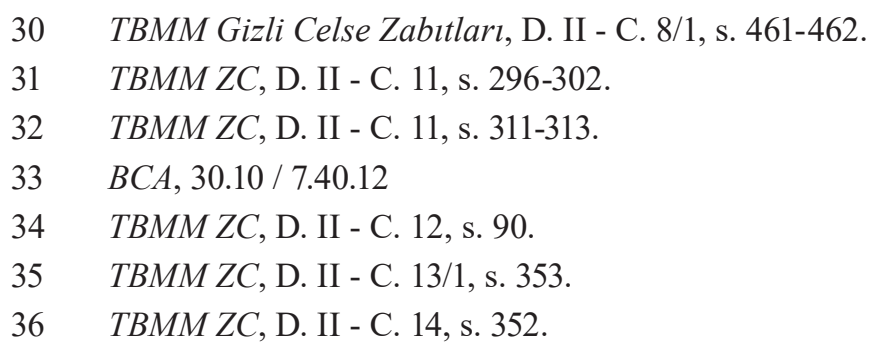


Urfa, Suruç, Bilecik, Dersim, Maraş, Bayezit, Sivas, Trabzon ve Kozan vilayetlerinde yatılı okul açılması için ilgili 400.000 liralık ödeneğin 600.000 liraya çıkarılması isteniyordu. Maarif Vekili Hamdullah Suphi (Tanrıöver) Bey’in sıcak bakmadığı önerge genel kurulda yapılan oylama sonucunda kabul edilmedi. ${ }^{37}$

1925 yılı Vakıflar Genel Müdürlüğü bütçesi görüşmelerinin yapıldığı 2 Nisan 1925 tarihli oturumda Antalya milletvekili Rasih (Kaplan) Bey’in öncülüğünde 50 milletvekilinin imzası ile verilen önergeye Malatya milletvekili Mahmut Nedim Bey de imza attı. "Hafiz-ı Kur'an yetiştirmek üzere evkaf masarif bütçesinin altıncı faslına (Huffaz yetiştiren zevat ücüratı) namıyla açılacak on üçüncü maddeye beheri elli lira ücretli on huffaz yetiştiren zevat ücreti olan senelik altı bin liranın vaz ve kabulünü arz ve teklif eyleriz" şeklindeki önerge oylanarak komisyona sevk edilmesi kararlaştırıldı. ${ }^{38}$

Mahmut Nedim Bey'in 1324 Temmuzundan itibaren 1339 senesi gayesine kadar bilcümle matlubat ve düyun-u hazinenin suret-i mahsubuna dair olan kanunun altıncr maddesinin tefsiri hakkındaki önergesi 18 Mart 1926 tarihli oturumda Meclis Başkanlığı tarafından Kavanin-i Maliye Encümeni'ne sevk edildi. ${ }^{39}$ Söz konusu komisyonun önergeye yönelik hazırladı̆̆ 1 mazbata 26 Mayıs 1926 tarihli oturumda kabul edildi. ${ }^{40}$

17 Mayıs 1926 tarihli meclis oturumunda gündeme alınan 1926 yılı Ziraat Vekâleti bütçe tasarısı görüşmelerinde Malatya milletvekili Mahmut Nedim Bey kamuda görev yapan veterinerlere ikramiye verilmesini talep eden şu önergeyi verdi: "1926 bütçesinde memurini baytariyeye hiç bir güna zammiyat icra edilemediği anlaşıldiğından vebayı bakari mücadelesinde bir seneyi mütecaviz zamandan beri geceli gündüzlü fartı mesaî ile ve cüzî maaşlarla çalışmakta bulunan memurini mumaileyhimin bir taraftan istifa etmekte ve hariçte daha fazla maaşla vazife bulmakta olmalarına mebni buna mahal kalmamak üzere 1926 bütçesinde 615 inci faslın 3 üncü emrazı müstevliyei hayvaniye tertibinde mevzu 260.000 liradan 20.000 liranın bittefrik memurini baytariyeye hizmetleri derecesinde ikramiye suretiyle itasinı teklif eylerim”"

Muvazene-i Maliye Encümeni adına söz alan Çankırı milletvekili Mustafa Abdülhalik (Renda) Bey komisyonun bütçede fasıllardan tenzilat yapılmasına karşı olduğunu vurgulayarak önergeyi kabul etmediğini belirtti. ${ }^{41}$

Mahmut Nedim Zabcı'nın ikinci dönem yasama süreci içerisinde imza attığı kanun teklifleri ise şunlard1:

Mahmut Nedim Bey TBMM'nin 19 Şubat 1924 tarihli oturumunda Şimendifer vesair inşaatı lazime için istihkâm kıtaatı teşkili hakkında kanun teklifi verdi ve teklif Layiha Encümeni'ne sevk edildi. ${ }^{42}$ Layiha Encümeni'nin müzakereye değer bulduğu teklif 21 Şubat 1924 tarihli oturumda Müdafaa-i Milliye Encümeni'ne havale edildi. ${ }^{43}$ İlgili komisyon bu teklife yönelik mazbatasını

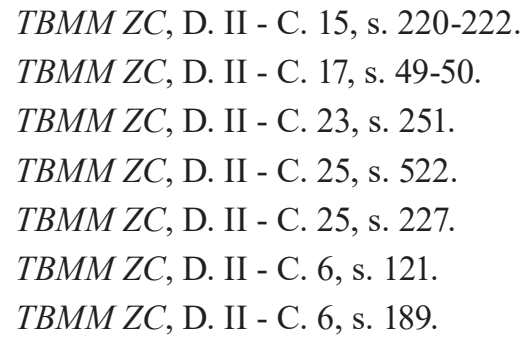


son yasama yılında Meclis Başkanlığına sundu. 3 Ocak 1927 tarihli oturumda Müdafaa-i Milliye Encümeni "istihkâm kıtaatı tezyit edilmiş olduğundan” dolayı teklife gerek kalmadığını belirtti ve genel kurul mazbatayı kabul etti. ${ }^{44}$

Mahmut Nedim Bey'in Harita Dairesi kadrosunun tevsii ve mülhak bir bütçe ile idaresi hakkındaki teklifi kanunisi meclisin 29 Mart 1924 tarihli oturumunda incelenmek üzere Layiha Encümeni'ne havale edildi. ${ }^{45}$ İlgili komisyon mazbatasında teklifin müzakereye değer bulunduğunu belirtti ve teklif 5 Nisan 1924 tarihli oturumda Müdafaa-i Milliye ve Muvazene-i Maliye encümenlerine sevk edildi. ${ }^{46}$ Ancak Mahmut Nedim Bey’in de üyesi olduğu Müdafaa-i Milliye Encümeni teklifi reddetti. Söz konusu komisyon mazbatasında “...Malatya Mebusu Mahmut Nedim Bey'in teklif-i kanunisi Encümenimizce tetkik edildi. Mesele 22 Nisan 1341 tarih ve 657 numaralı Harita Müdüriyet-i Umumiyesi Kanunu ile halledildiğinden tayini muameleye mahal kalmadığına karar verilmiştir” deniliyordu. Mazbata 16 Kasım 1925 tarihli meclis oturumunda genel kurul tarafindan kabul edildi. ${ }^{47}$

Urfa milletvekili Ali Fuat Bey ve 48 milletvekilinin imzasını taşıyan Orta Tedrisat Muallimleri Kanunu'nun ondördüncü maddesinin tadili hakkında kanun teklifi meclisin 17 Kasım 1924 tarihli oturumunda gündeme alındı. Malatya milletvekili Mahmut Nedim Bey'in de imzasının bulunduğu teklifte söz konusu maddenin "Daimi, muvakkat muallimler Artvin, Ardahan, Erzurum, Ergani, Bayezit, Bitlis, Hakkâri, Siirt, Süleymaniye, Kars, Kerkük, Genç, Muş, Musul, Van, Dersim, Erzincan, Sivas, Malatya, Diyarbekir, Mardin, Şarkikarahisar, Urfa, Siverek, Elâziz vilayetlerindeki orta tedrisat mekteplerine gönderildikleri ve o vilayetlerin sakinlerinden olmadıkları takdirde maaş ve fevkalâde tahsisatları mecmuun yarısı kadar zam alırlar" şeklinde olması talep ediliyordu. Teklifi inceleyen Layiha Encümeni 20 Mart 1924 tarihinde teklifin müzakereye değer olduğuna yönelik kararını Meclis Başkanlığına sundu. Daha sonra Maarif Encümeni’ne sevk edilen teklif hakkında bu komisyonda yapılan müzakereler sonucunda hazırlanan mazbata 20 Nisan 1924 tarihinde Meclis Başkanlığına sunuldu. Maarif Encümeni söz konusu mazbatasında teklifte adı geçen vilayetlerden sadece Diyarbakır, Mardin, Urfa ve Siverek'in ilgili kanuna eklenebileceğine karar verdi. Teklif ve mazbata üzerinde yapılan genel kurul müzakerelerinde Çorum milletvekili Mustafa Bey'in teklifin bütçe ve ödenekleri ilgilendiren yönü itibariyle Muvazene-i Maliye Encümeni'ne gönderilmesi önerisi oylanarak kabul edildi. ${ }^{48}$

Meclisin 19 Mart 1927 tarihli oturumunda İstanbul milletvekili Hamdullah Suphi Bey’in öncülüğünde 102 milletvekilinin imzası ile verilen Samipaşazade Sezai Bey'e Hidemat-ı Vataniye tertibinden maaş tahsisi hakkındaki kanun teklifinde Malatya milletvekili Mahmut Nedim Bey’in de imzası bulunuyordu. Türk edebiyatının önde gelen yazarlarından Samipaşazâde Sezai Bey’e ekonomik durumunun yetersiz oluşu nedeniyle 10.000 kuruş maaş bağlanmasını öngören kanun teklifi şöyle idi:

"Namık Kemal ve Şinasi neslinin, Abdülhak Hamit'le beraber memlekete son bergüzarl kalan meşhur büyük edibimiz Sami Paşazade Sezai Bey’in bugün metruk

$\begin{array}{ll}44 & T B M M Z C, \text { D. II - C. } 28, \text { s. } 242-243 . \\ 45 & T B M M Z C, \text { D. II - C. } 8, \text { s. } 60 . \\ 46 & T B M M Z C, \text { D. II - C. } 8, \text { s. } 302 . \\ 47 & T B M M Z C, \text { D. II - C. } 19, \text { s. } 125 . \\ 48 & T B M M Z C, \text { D. II - C. } 10, \text { s. } 285-287 .\end{array}$


bir halde kaldığına kemal-i teessüfle şahit ve muttali olmaktayız. Tarihî şanlı namın zikrettiğimiz bu zat yalnız edebiyat alemimizin en mühim rükünlerinden biri değil aynı zamanda millî ve siyasî inkılabımızın en fedakâr, en gayyur haddim ve mübeşşirlerindendir. Yeni Türkiye’nin tekevvününde unutulmaz hizmetleri sebkat etmiş ve yarım asırlık hayatı zulme, cehle karşı pek çetin mücadelelerle geçmiş olan Sami Paşazade Sezai Bey, bin türlü fedakârlıklara ve feragatlara tahammül ederek takibe başladiğl yüksek gayenin tahakkuku gününde çok sevdiği ve yolunda bütün hayatını feda ettiği millet ve vatan tarafindan her türlü iltizam ve sahabete lâyıtır. Bütün medenî memleketlerde fikir yolunda rehber vazifesini görmüş bu gibi büyük şahsiyetlerin mazhar oldukları refah ve vüsatla kendi fikir ve kalem büyüklerimizin vaziyeti arasındaki elim fark, bizi teessürle düşündürecek kadar acıdır. Daima ilim ve sanat vadisinde Türk Milleti'ne yüksek eserler birakmış olanları şefkat ve muhabbetle ve teşvik ve hürmetle teyit ve iltizam eden Millet Meclisimizin tamamıyla tarihe karışan muazzam bir intibah devrinin son abidelerinden biri olan Sezai Bey hakkinda da Hidemat-l Vataniye tertibinden bir maaş tahsisini rica ve teklif ediyoruz"

145 milletvekilinin katıldığı oylamada 140 kabul, 2 ret ve 3 çekimser oyu verildi. Böylece teklif kabul edilerek Samipaşazâde Sezai Bey’e vatana hizmet kaleminden maaş bağlandı. ${ }^{49}$

Mahmut Nedim Bey ikinci meclis döneminde genel kurulda çeşitli kanun tasarıları üzerindeki görüşlerini de bildirdi. Cumhuriyetin ilk yıllarında toplumsal alanda yapılan inkılaplar arasında yeni saat sistemine ve miladi takvime geçiş düzenlemeleri de yer almaktayd1. Bu düzenlemeleri içeren kanun tasarıları hükümet tarafından Meclis Başkanlığına 11 Kasım 1925 tarihinde sunuldu. Meclis Başkanlığı bu tasarıları incelemek üzere özel bir komisyon oluşturdu. Başkanlığını İstanbul milletvekili Ahmet Muhtar Bey’in yaptığı bu komisyonun mazbata muharriri Malatya milletvekili Mahmut Nedim Bey idi. İlgili komisyonun hazırladığı mazbatalar 22 Aralık 1925 tarihinde Meclis Başkanlığına iletildi. ${ }^{50}$

Saatlerin Yirmi Dörde Taksimi Suretiyle İstimaline Dair Kanun Lâyihası TBMM'nin 26 Aralık 1925 tarihli oturumunda gündeme alındı. Tasarının müzakerelerinde komisyon sözcüsü olarak Mahmut Nedim Bey hazır bulundu. Günü 24 saate bölen tasarının müzakeresi birçok milletvekilinin fikirlerini sunduğu uzun tartışmalara sahne oldu. Komisyon adına Mahmut Nedim Bey milletvekillerine tasarı hakkında bilgiler verirken, gelen soruları da cevapladı. Görüşmelerde ilk sözü alan Trabzon milletvekili Muhtar Bey tasarıya karşı olmadığını ancak söz konusu sistemi uygulayan ülkelerin resmi işlemlerde zorunluluk getirirken, halkı serbest bıraktıklarını “... kanunen herkese cebindeki saati yirmi dört saat olarak kullanacaksın diye bir mecburiyet tahmil etmemişlerdir..." diyerek hatırlattı. Tasarıda Türkiye için referans olarak Greenwich'e göre İzmit'ten geçen 30 derece boylamı esas alınıyordu. Muhtar Bey bu konuya da değinerek tüm ülkede sadece İzmit'ten geçen meridyeni esas almaktansa ülkenin ortasından geçen meridyenin kabul edilmesinin daha iyi olabileceğini ancak o zaman da Avrupa ile uyum sağlanamayacağını belirterek üç ayrı çözüm önerisi sundu. Bunun üzerine Mahmut Nedim Bey 1914 yılında Avrupa'da yapılan uluslararası bir kongrede tüm ülkelerin saatlerini Greenwich rasathanesine göre ayarladıklarını

\footnotetext{
$49 T B M M Z C$, D. II - C. 30, s. 148-151, 155.
}

$50 \quad T B M M Z C$, D. II - C. 20, s. 1-6. 
ve İzmit merkezli 30 derecelik boylamın tüm ülkede iki saatlik bir fark yaratmayacağını söyledi. Muhtar Bey'in görüşleri hakkında ise şu yorumları yaptı: “... ahaliyi icbar etmeyelim dediler. Ahaliyi icbar değil zaten hiç kimseyi icbar edemeyiz. Fakat hükümet ahali ile olan bütün muamelâtımda bu saati istimal edecektir. Binaenaleyh ahalide mecburdur. Şimendiferine binecek, malını götürecek, vaktinde, saatinde yetişmezse kendi işini, intizamını şaşırır. Mamafih mecburiyet değil zaruret vardir. Bu saatin hükümet tarafindan teklifi ile gayet muvafik gayet ani bir usul tatbik edilmiştir. Bunda bir müşü̈lata da maruz kalınamaz. Bidayeten bir iki ay saatin yirmi dörde taksimi biraz müşülata maruz kalırsa da bilâhare anlaşılır..."

Tasarının "İzmit civarından geçip Giriniç'e nazaran otuzuncu derecede bulunan nisfünnehar bütün Türkiye Cumhuriyeti saatleri için esastır" ş̧eklindeki ikinci maddesinin müzakeresinde Karesi (Balıkesir) milletvekili Vehbi Bey madde aleyhinde söz alarak boylam konusunun uzmanlara bırakılması gerektiğini ve bu kararın rasathaneler tarafından verilmesini talep ederek maddenin iptalini istedi. Mahmut Nedim Bey maddeyi savundu ve İzmit'in esas boylam dairesi olduğunu, 45 . meridyenin Erivan ve Süleymaniye'den geçtiğini ve ülke içi ulaşım yetersizliğinin de göz önüne alındığını şu sözlerle ifade etti:

“İmit'ten itibaren 3-4 derece garpta Edirne var ki bizim hududumuzun müntahasırdır. Sonra saat mintıkası olarak İzmit'ten itibaren 7,5 derece şarkta Fatsa vardir. Esasen, Fatsa-Kangal- Gaziantep hattiyla Edirne hattı arasindaki mevakide bir saat kullanılması lâzım gelir. Bunun şarkinda 45 derece Erivan'dan geçer. Demek ki oradan itibaren Fatsa'ya kadar bizim 7,5 derecelik bir yerimiz vardir. Orada bașka bir saat kullanmaklı̆gımız lâzım geliyor. Fakat bugünkü günde icab-ı hal bunu muvafik görmüyor. Çünkü oralara gitmek için şimendifer yoktur ve böyle bir saate ihtiyaç yoktur. Fakat bilahare oralara şimendifer yapılır, bura ile o nısfünnehar dairesi arasindaki vasita temin edilir. Onun için hükümet tarafindan verilen teklifte, iki saat diye tespit edilmişti. Biz bunu kaldırdık, İzmit nısfünneharı esastır dedik. Zaten İzmit esastır. Esas İzmit nısfünnehar dairesidir ki hükümet isterse bütün memlekete 7,5 derece sağındakini ayrica bir saat olarak kabul eder. Maksat bunu kanuna koymamaktır. Fennen kabul edilmiş bir şeydir. Fenni olan bir şeyi hükümet icabı geldikçe tatbik edecek"

İstanbul milletvekili Yusuf Akçura konuya başka bir açıdan yaklaşarak ülke savunması ve askeri harekât açısından da saat sisteminin önemli olduğunu ve Genelkurmay Başkanlığı'nın iki saat kullanımı vb konularda neler düşündüğünü sordu. Mahmut Nedim Bey ülkede tek saat bulunmasının esasen uygun olduğunu ve Türkiye'nin en batısındaki bir yerle Kars arasında takriben 47-48 dakikalık bir fark bulunduğunu söyledi. Uzmanların 30-35 dakikaya kadarki farkları normal karşıladıklarını hatırlattı ve buna göre Türkiye'de fazladan 12-13 dakikalık bir fark olduğunu belirtti. Trabzon milletvekili Muhtar Bey'in İzmit'ten en uzak mesafeye kadar olan farkın 72 dakikayı bulacağını söylemesi üzerine Mahmut Nedim Bey hesap yaparak 50 dakikalık bir fark çıkacağını söyledi ve Türkiye'de tek saat kullanılacağını, Greenwich'e nazaran İzmit'in tam iki saat ileride olduğunu vurguladı. İkinci madde için verilen değişiklik önergeleri genel kurul tarafından reddedilerek söz konusu madde aynen kabul edildi. Mahmut Nedim Bey bu süreçte Gelibolu milletvekili Celal Nuri Bey'in ilk maddeye yönelik arkadaşları ile birlikte verdiği "Türkiye Cumhuriyeti dâhilinde gün, gece yarısından başlar ve saatler sıfirdan yirmi dörde kadar tadad olunur" şeklindeki değişiklik önergesini komisyonun kabul ettiğini sadece "tadad olunur" yerine "sayllır" kelimesinin eklenmesini istediklerini açıladı. Genel kurul söz konusu önergeyi 
kabul etti ve ilk madde böylece son şeklini aldı.

Üçüncü maddenin müzakerelerine geçilirken Trabzon milletvekili Muhtar Bey tasarıya bir madde eklenmesini talep etti. Avrupa'da uygulanan yaz ve kış saatine değinen Muhtar Bey Türkiye'de hiçbir dönem bu tür bir uygulama yapılmadığını ancak mütareke döneminde işgalci devletlerin bu uygulamayı Türkiye'de başlattıklarını ve hâlâ sürdüğünü belirtti. Fransa gibi bazı ülkelerin bu uygulamayı terk ettiğini de hatırlatan Muhtar Bey Türkiye'de işgalcilerden kalan bu uygulamanın kaldırılmasını teklif etti. Mahmut Nedim Bey ise söz konusu durumun müzakere edilen kanunla bir ilgisi bulunmadığını söyledi. Üçüncü ve dördüncü maddeler de aynen kabul edildikten sonra genel kurul tasarının tamamını oylayarak kabul etti. Böylece Türkiye' de uygulanan 12 saatlik sistem kaldırılarak günü 24 saate bölen yeni saat sistemi yasalaşt1. ${ }^{51}$

Meclisin 26 Aralık 1925 tarihli oturumunda müzakere edilen bir diğer kanun tasarısı Rumî takvimin ilgasıyla beynelmilel takvimin resmi devlet takvimi ittihazı hakkında kanun lâyihası idi. Tasarının "Hicrî kamerî takvimi kemakân ahval-i mahsusada istimali caizdir" şeklindeki üçüncü maddesi müzakere edilirken, tasarıyı inceleyen özel komisyonun mazbata muharriri Mahmut Nedim Bey madde içerisinde değişiklik isteyen bir önerge verdi. Maddenin sonuna "Şu kadar ki kameri ayların birinci günleri rasathanece tespit olunur" cümlesinin eklenmesini öneren Mahmut Nedim Bey Trabzon milletvekili Muhtar Bey’in önerge hakkında bilgi istemesi üzerine kürsüye gelerek şu açıklamayı yaptı: "Bugün ilmi heyette fennin terakkiyatı fevkaladedir. Bugünkü ayların değil, bundan beş yüz sene sonraki ayların günlerini de tespit etmek mümkündür. Halbuki bugün vaziyet nedir? Burada bayram oluyor, öbür tarafta bayram olmuyor. Sonra ramazan günlerini tayin etmek için de müşkülata maruz kalıyoruz. Bütün memleketin içinde umumi bir hercümerç oluyor. Fennin terakkiyatı karşısında ayın bu gününü bilmiyorum demek veyahut iki adam gitsin de mahkemeden ilâm alsın ondan sonra bayram olsun, bu doğru değildir. Bendeniz bir fikranın ilavesini rica ediyorum ki, bu rasathanece nüsbet ve muayyendir. Bütün Türkiye'de, muharremin birinci günü şudur, seferin birinci günü budur, ramazan şu gündür diye ilan edilir ve bu suretle ayların birinci günü nihayetine kadar tespit edilir ve bu teşevvüşten de kurtuluruz"

Mahmut Nedim Bey’in Ramazan ayının tespitine ilişkin yaptığı bu açıklama üzerine Gümüşhane milletvekili Hasan Fehmi Bey bu duruma göre Ramazan'ın Şubat ayına gelip gelemeyeceğini sordu. Mahmut Nedim Bey bu soru üzerine önergesini geri almak istediğini belirtti. Ancak Trabzon milletvekili Muhtar Bey Mahmut Nedim Bey’in önergesini kabul ettiğini söyledi. Sinop milletvekili Rıza Nur Bey ise tüm milletlerin bayramlarının hangi tarihe denk geldiğini aylar öncesinden bildiklerini ancak Türk milletinin bunu bilmediğini vurguladı. Ay görme tekniğiyle bayram tarihinin belirlendiğini ve bunun da tam olarak kestirilemediği için birçok soruna neden olduğunu belirten Rıza Nur Bey bu konuda Lozan Konferansı günlerinde yaşadığı bir hatırasını anlattı: “...Ecnebiler adama bayramını ne vakittir diye soruyorlar. Halbuki söyleyebilirseniz söyleyiniz, ne mahcubiyettir. Bu, Lozan'da bizim başımıza geldi. Karşımızdaki murahhaslar bize bir cemile yapmak için tatil yapacaklard, bayramınız ne vakittir diye bize sordular. Bizde söyleyemedik, çok ayıp oldu..." Rıza Nur Bey bu ve benzeri durumların ortadan kaldırılması için bilimsel yöntemlerle tarihlerin tespit edilmesini istedi. Bu düşüncelere karşı çıkan Gelibolu milletvekili Celal Nuri Bey "ayın safahatı ve devri güneşin devri gibi fennen sabit olamaz..." 
derken Trabzon milletvekili Muhtar Bey “...Rasathane bugün ayın hangi senenin hangi gününde hangi saatinde muhakda olduğunu yani şems, kamer ve arzın üçününde bir araya geldiği dakikayı pek iyi hesap eder. Sonra rasathane bu muhaktan kaç saat sonra gurre olabilir, yani ay görülecek şekle gelebilir, onu da ispat etmeye muktedirdir. Misal bir çok zaman biz burada ay yeni ve eski aydır diye tespit etmeye çalışlyorken, ramazan bugündür yarındır derken rasathane bize gösterdi...” diyerek Mahmut Nedim Bey’in geri almak istediği önergesini savundu. Bu tartışmalar üzerine Mahmut Nedim Bey'in "Bendenizin verdiğim takririn Meclisi Âlice hassasiyet-i mucip olduğunu görüyorum ..." sözleriyle tekrar sunduğu önergesi genel kurul tarafından kabul edildi ve söz konusu maddenin son şekli şöyle oldu: "Hicri kameri takvim öteden beri olduğu üzere ahval-i mahsusada kullanllır. Hicrî kamerî aylarin mebdeini rasathane resmen tespit eder",52

\section{3. Üçüncü Meclis Dönemi Faaliyetleri (1927-1931)}

1927 seçimleri sonucunda açılan TBMM'nin üçüncü döneminde rejimin laikleştirilmesine yönelik reformlara devam edildi. Bu bağlamda 9 Nisan 1928'de anayasanın ikinci maddesinde yer alan "Türkiye Devleti'nin dini, din-i Islamdır" ibaresi kaldırıld..$^{53}$

Bu dönemde Cumhurbaşkanı Mustafa Kemal Paşa Fethi (Okyar) Bey ile birlikte Türkiye'de çok partili rejime geçişi sağlamaya yönelik bir adım attı. 12 Ağustos 1930 tarihinde Fethi Bey'in genel başkanlığında kurulan Serbest Cumhuriyet Fırkası Cumhuriyet Halk Fırkası'ndan bünyesine katılan bazı milletvekilleriyle birlikte meclis grubunu oluşturdu. Kuruluşundan kısa bir süre sonra başlayan belediye seçimlerine katılan SCF bazı yerlerde seçimi kazandı. Seçimlerden sonra iktidarın baskı ve yolsuzluklar yaptığını ileri süren ve bu konuda Dahiliye Vekâleti hakkında bir gensoru önergesi de veren Fethi Bey ve arkadaşları 17 Kasım 1930 tarihinde partilerini feshetme kararı aldılar. ${ }^{54}$ Böylece tek parti rejimi üç aylık bir kesintiden sonra devam etti.

Mahmut Nedim Zabcı üçüncü dönem boyunca Nafia ${ }^{55}$ ve Maliye ${ }^{56}$ komisyonlarında görev yaptı. Ayrıca Milli Mücadele yıllarındaki hizmetlerinden dolayı İstiklâl Madalyası ile ödüllendirildi. Mahmut Nedim Bey madalyasını meclisin 20 Mayıs 1928 tarihli oturumunda düzenlenen törende TBMM Başkanı Kâzım (Özalp) Paşa'dan aldı. ${ }^{57}$

Zabcı'nın dönem boyunca Meclis Başkanlığı'na sunduğu önergeler şöyle idi:

Mahmut Nedim Bey Kadastro tahrir kanun lâyihasının muhtelit bir encümende müzakeresine dair önergesini 7 Şubat 1929 tarihinde Meclis Başkanlığına sundu. Önergede şu görüşler dile getiriliyordu: "Kadastro gibi memleketi baştanbaşa alakadar eden pek mühim bir layiha-yl kanuniye Yüksek meclisin tasvibine arz edilmiştir. Bu layiha şumulu itibarlyla Bütçe, Maliye, Adliye, Dâhiliye ve Nafia encümenlerini alakadar ettiğinden mezkûr encümenlerden intihap edilecek üçer azadan mürekkep bir muhtelit encümen teşkili ile orada müzakeresini arz ve teklif eylerim"

\footnotetext{
52 TBMM ZC, D. II - C. 20, s. 276-281.

53 Cemal Avc1, III. Dönem Türkiye Büyük Millet Meclisi’nin Yapisı ve Faaliyetleri (1927-1931), Atatürk Araştırma Merkezi Yayınları, Ankara, 2000, s. 87-94.

54 Tunaya, Türkiye’de Siyasi Partiler 1859-1952, s. 622-631; Tevfik Çavdar, "Serbest Furka”, Cumhuriyet Dönemi Türkiye Ansiklopedisi, C. 8, s. 2052-2059.

55 TBMM ZC, D. III - C. 1, s. 21.

$56 T B M M Z C$, D. III - C. 13, s. 11; TBMM ZC, D. III - C. 22, s. 10.

57 TBMM ZC, D. III - C. 4, s. 208.
} 
Meclisin 11 Şubat 1929 tarihli oturumunda gündeme alınan bu önerge üzerine söz alan Bütçe Encümeni Başkanı Edirne milletvekili Şakir Bey gerek iş yoğunluğu gerekse iç tüzük gereği karma komisyonların bakanlıklara bağlı komisyonlar tarafından oluşturulabileceğinden dolayı başında bulunduğu komisyonun teklif edilen karma komisyona katılmamasını istedi. Önerge sahibi Mahmut Nedim Bey de bu görüşü destekledi. Önerge aleyhine söz alan Konya milletvekili Musa Kâzım Bey ise karma komisyonların sayılarının arttığını ve komisyonların asli görevlerini yapamaz hale geldiklerini belirterek bu tür konularda karma komisyonlara gerek olmadığını söyledi. Bunun üzerine söz alan Mahmut Nedim Bey şu açıklamayı yaptı:

"Eski nizamnameye göre tapu ve kadastro işleri için bir tapu encümeni vard yeni nizamnamede her vekâletin kendine ait olan hususat için ayrica bir encümen teşkil edildiği halde Tapu hariçte kaldı. Malum-u âlileridir ki tapu ve kadastro mühim bir meseledir. Dört beş seneden beri bu kanun layihası hazırlanıp meclise gelmek üzere idi, nihayet gelmiştir. Adliye, Maliye, Dâhiliye ve Bütçe encümenlerine esasen kanun havale edilmiştir. Şimdi bu kanunu en ziyade alakadar eden encümenlerden biri de Nafia encümenidir. Çünkü fen işleridir. Maliye ve Bütçe encümenleri tabiatıyla meşgul olacaklardır. Dâhiliye ve Adliye encümenlerine keza... Ĕ̆ger biz kanunu hal-i tabisi ile encümenlere gönderecek olursak zannediyorum ki layı-l veçhile ve esash bir surette mütalaa edilmek imkânı hâsıl olmaz ve hem de çok zaman geçer. Onun için istirham ederim eski tapu encümenine mukabil olarak yeni bir muhtelit encümen teşkil edelim. Zaten nizamname-i dahili müzakere edildiği zaman bendeniz encümenin nazarı dikkatini celp etmiştim. O zaman dediler ki tapu ve kadastro layihası meclise geldiği vakit teklif edersiniz bir muhtelit encümen teşkil edilir ve o encümende bu işler tetkik edilir. Mamafih rey-i âlilerine vabestedir, arzu buyrulursa en muvafik şekil bu olacaktır"

Bu açıklamanın ardından yapılan oylama sonucunda genel kurul önergeyi kabul etti. ${ }^{58}$

Mahmut Nedim Zabcı'nın üçüncü dönem yasama süreci içerisinde imza attığı kanun teklifleri ise şunlard1:

Yozgat milletvekili Tahsin Bey’in öncülüğünde 24 milletvekilinin imzası ile 19 Aralık 1927 tarihinde Meclis Başkanlığına sunulan Kastamonu Mebusu Merhum Mahir Efendi Ailesine Hidemat-ı Vataniye Tertibinden Maaş Tahsisi hakkındaki kanun teklifine imza verenler arasında Malatya milletvekili Mahmut Nedim Bey de vardı. Kanun teklifinin ilk maddesinde "Kastamonu Mebusu merhum Ahmet Mahir Efendi'nin zevcesi Cemile Hanım'a eytam ve eramil maaşı kat edilmek üzere kaydı hayat şartıyla Hidemat-ı vataniye tertibinden kırk, dul kerimesi Bideyre ve iki bakire kerimeleri Rabia ve Tayyibe hanımlara teehhüllerine kadar yirmişer lira maaş tahsis olunmuştur" deniliyordu.

Bütçe Encümeni teklifi inceledi ve 22 Nisan 1928 tarihinde Meclis Başkanlığına sunduğu mazbatasında maddeye son şeklini şöyle verdi: "Kastamonu Mebusu merhum Ahmet Mahir Efendi'nin zevcesi Cemile ve kerimeleri Bideyre, Rabia, Tayyibe Hanımlara Maliye Vekâleti bütçesindeki masarifi gayri mahsuse tertibinden üç bin liranın ikramiye olarak itasına mezuniyet verilmiştir." 5 Mayıs 1928 tarihli oturumda müzakere edilen kanun teklifinin maddeleri kabul 
edildi. ${ }^{59} 12$ Mayıs 1928 tarihli oturumda ise ikinci müzakere yapıldı ve teklifin geneli kabul edilerek kanunlaştırıld1. ${ }^{60}$

Malatya milletvekili Mahmut Nedim Bey 27 Kasım 1930 tarihinde Ankara şehri Imar Müdürlüğ̈ tarafindan inşa edilen hâl hakkındaki kanun teklifini Meclis Başkanlığına sundu. Meclis Başkanlığı ise teklifi Dahiliye Encümeni'ne havale etti. ${ }^{61}$ Ancak Mahmut Nedim Bey meclisin 29 Aralık 1930 tarihli oturumunda bir önerge vererek komisyonda olan kanun teklifinin geri verilmesini istedi. Oturumu yöneten Meclis Başkanvekili Refet Bey kanun teklifinin iade edildiğini belirtti. ${ }^{62}$

\section{Dördüncü Meclis Dönemi Faaliyetleri (1931-1935)}

1931 y1lında toplanan dördüncü dönem TBMM'de özellikle kültürel alanda önemli reformlar yapıldı. Kapatılan Türk Ocakları'nın yerine 1932'de Halkevleri açıldı. 1933 yılında Darülfünun İstanbul Üniversitesi'ne dönüştürüldü. Türk Tarih ve Dil Kurumları açıldı. Ekonomide devletçilik modeli benimsenerek beşer yıllık sanayi ve kalkınma planları hazırlandı. Soyadı kanunu kabul edildi ve dönemin sonlarında kadınlara seçme ve seçilme hakkı tanınd1. ${ }^{63}$

Mahmut Nedim Zabcı dördüncü dönem boyunca Maliye ${ }^{64}$ ve Milli Müdafaa ${ }^{65}$ komisyonlarında görev yapt1.

$\mathrm{Bu}$ dönem yasama çalışmaları içinde Cumhuriyetin onuncu yıldönümü kutlamalarının hazırlıkları da yapıldı. Bu çerçevede Türkiye'yi ziyaret eden yabancı heyetlerden biri Macar parlamenterlerden oluşuyordu. Türkiye ile Macaristan arasındaki yakın ilişkileri de simgeleyen bu ziyareti iade etmek amacıyla TBMM Başkanlığı 10 milletvekilinden oluşan bir heyet oluşturarak Macaristan'a gönderme kararı aldı. Aralarında Malatya milletvekili Mahmut Nedim Bey'in de bulunduğu bu heyet meclisin 21 Nisan 1934 tarihli oturumunda genel kurulun onayından geçti. ${ }^{66}$

Mahmut Nedim Zabcı'nın dördüncü dönem yasama süreci içerisinde imza attığı kanun teklifleri ise şunlardı:

Giresun milletvekili Hakkı Tarık (Us) Bey ile birlikte 118 milletvekilinin imzası ile 23 Kasım 1931 tarihinde Meclis Başkanlığına sunulan ve anayasanın 95. maddesinin değiştirilmesini talep eden kanun teklifinde Malatya milletvekili Mahmut Nedim Bey'in de imzası vardı. 28 Kasım 1931, 5 Aralık 1931 ve 10 Aralık 1931 tarihlerinde müzakere edilen bu teklif oybirliğiyle kabul edildi ve ilgili anayasa maddesi şu şekle dönüştürüldü: "Muvazene-i Umumiye Kanunu lâyihası ve buna bağlı bütçeler ve cetveller ile mülhak bütçeler meclise mali yılbaşından en az üç ay evvel

\footnotetext{
$59 T$ TBMM ZC, D. III - C. 4, s. 43.

60 TBMM ZC, D. III - C. 4, s. 105.

61 TBMM ZC, D. III - C. 22, s. 88.

$62 T B M M Z C$, D. III - C. 23, s. 51.

63 Ahmet Demirel, Tek Partinin İktidarı Türkiye'de Seçimler ve Siyaset (1923-1946), İletişim Yayınları, İstanbul, 2013, s. 155-164.

$64 T B M M Z C$, D. IV - C. 1, s. 28; TBMM ZC, D. IV - C. 4, s. 10.

$65 T B M M Z C$, D. IV - C. 10, s. 10; $T B M M Z C$, D. IV - C. 18, s. 12; $T B M M Z C$, D. IV - C. 25, s. 11.

66 TBMM ZC, D. IV - C. 21, s. 94.
} 
takdim olunur "'67

Malatya milletvekili Mahmut Nedim Bey'in Isparta milletvekili Kemal Turan ile birlikte hazırladıkları Askeri ve mülki tekaüt kanununun 55 'inci maddesine bazı fikralar ilavesine dair kanun teklifi ise meclisin 17 Aralık 1931 tarihli oturumunda Maliye ve Bütçe encümenlerine sevk edildi. ${ }^{68}$

\section{Beşinci Meclis Dönemi Faaliyetleri (1935-1939)}

1935 yılında açılan beşinci meclis döneminde CHP rejimin niteliğine yönelik önemli kararlar aldı. Partinin dördüncü kurultayında alınan kararlar doğrultusunda 18 Haziran 1936 tarihinde Başbakan İsmet İnönü'nün yayınladığı bir genelge ile parti ile devletin kaynaştırılması süreci başlatıldı. Ülkenin ve partinin gelişimini hızlandırmak amacıyla alındığı belirtilen söz konusu kararlara göre İçişleri Bakanı CHP Genel Sekreterliğine, valiler de CHP il başkanlığına getiriliyorlardı. Bu genelge ile Genel Müfettişler de bölgelerindeki parti örgütü ve faaliyetlerinin denetçisi oldular. ${ }^{69} 5$ Şubat 1937 tarihinde ise CHP'nin altı ilkesi anayasanın ikinci maddesine eklenerek parti-devlet bütünleşmesi sağlanmış oldu ${ }^{70}$

Mahmut Nedim Zabcı beşinci dönem boyunca Maliye komisyonunda görev yapt1. ${ }^{71} \mathrm{Bu}$ dönem Zabcı'nın 27 yıllık parlamento kariyerinde yasama ve denetim faaliyetleri açısından en zayıf olduğu süreç oldu. Dönem boyunca genel kurulda söz almadığı gibi önerge, kanun teklifi, soru önergesi hazırlamadi.

\section{Altıncı Meclis Dönemi Faaliyetleri (1939-1943)}

1939 yılında açılan altıncı dönem TBMM'de dikkat çeken ilk nokta tek parti CHP içerisinde Müstakil Grup adıyla kurulan denetim organının varlığıydı. 1939 yılında toplanan CHP beşinci kurultayında oluşturulan bu grubun görevi hükümet ve partinin çalışmalarını denetlemek ve bir sonraki parti kurultayına faaliyet raporu sunmakt1. ${ }^{72}$ Böylece mecliste muhalefet partisinin olmayışının yarattığı eksiklik giderilmeye çalışılacak ve meclis çok partili rejime alıştırılmış olacaktı. Ancak bu grup kendisinden beklenen faydayı sağlayamadı. ${ }^{73}$ Hatay'ın Türkiye'ye katıldığı, Köy Enstitüleri'nin kurulduğu altıncı dönemde alınan Milli Korunma ve Varlık Vergisi kanunu gibi ekonomik kararlar da ise sürmekte olan İkinci Dünya Savaşı'nın etkileri görülmekteydi.

\footnotetext{
$67 T B M M Z C$, D. IV - C. 4, s. 29-35; TBMM ZC, D. IV - C. 5, s. 15-16; TBMM ZC, D. IV - C. 5, s. 33-34.

68 TBMM ZC, D. IV - C. 5, s. 48; BCA, 30.10/3.18.16

69 Nihan Yükseliman, Parti Devlet Bütünleşmesi, Gelenek Yayınları, İstanbul, 2002, s. 81-83; Mehmet Kabasakal, Türkiye’de Siyasal Parti Örgütlenmesi 1908-1960, Tekin Yayınevi, İstanbul, 1991, s. 132.

70 Mete Tunçay, “Cumhuriyet Halk Partisi (1923-1950)”, Cumhuriyet Dönemi Türkiye Ansiklopedisi, C. 8, s. 2021.

$71 T B M M Z C$, D. V - C. 1, s. 26; TBMM ZC, D. V - C. 6, s. 9; TBMM ZC, D. V - C. 13, s. 12; TBMM ZC, D. V - C. 20, s. 15; TBMM ZC, D. V - C. 27, s. 13.

72 Tuncay Dursun, Tek Parti Dönemindeki Cumhuriyet Halk Partisi Büyük Kurultaylarl, Kültür Bakanlığ1 Yayınları, Ankara, 2002, s. 106-107; Hakk1 Uyar, Tek Parti Dönemi ve Cumhuriyet Halk Partisi, Boyut Kitapları, İstanbul, 1999, s. 123-134; Cemil Koçak, Türkiye'de İki Partili Siyasî Sistemin Kuruluş Yılları (1945-1950) İkinci Parti, C. 1, İletişim Yayınları, İstanbul, 2010, s. 72-82; Osman Akandere, Millî Şef Dönemi Çok-Partili Hayata Geçişte Rol Oynayan İç ve Dış Tesirler 1938-1945, İz Yayıncılık, İstanbul, 1998, s. 132-141.

Hilmi Uran, Hatıralarım, Ankara, 1959, s. 344-345.
} 
Mahmut Nedim Zabcı altıncı dönem boyunca Maliye komisyonunda görev yapt1. ${ }^{74}$ Dönem boyunca Meclis Başkanlığı'na sunduğu önergeler şunlardı.

Mahmut Nedim Zabcı'nın Inhisarlar beyiyelerinin üçte birinin harp malûllerine ve şehit yetimlerine tahsis ve tevziine dair 1485 sayll kanunun 2'nci maddesinin son fikrasinın tefsiri hakkında verdiği önerge 27 Aralık 1940 tarihli oturumda Milli Müdafaa, Maliye ve Bütçe encümenlerine sevk edildi. ${ }^{75}$ Ancak Zabc1 28 Mayıs 1941 tarihinde başkanlığa sunduğu şu önerge ile komisyonlarda olan önergesini geri çekmek istediğini belirtti: "Inhisarlar beyiyelerinin üçte birinin harp malûllerine ve şehit yetimlerine tahsis ve tevziine dair 1485 sayll kanunun ikinci maddesinin son fikrasının tefsiri hakkındaki 4/30 sayıl tefsirin intacına lüzum kalmamasına binaen iadesine yüksek müsaadelerini istirham ederim"

2 Haziran 1941 tarihli oturumda genel kurula sunulan iade önergesi TBMM Başkanvekili Şemsettin Günaltay tarafından uygun görülerek kabul edildi. ${ }^{76}$

Mahmut Nedim Zabcı'nın altıncı dönem yasama süreci içerisinde imza attığı kanun teklifleri ise şunlard1:

Malatya milletvekili Mahmut Nedim Zabcı'nın hazırladı̆̆ 1 Askerî ve mülkî tekaüd kanununun 39'uncu maddesine bir fikra ilavesine dair kanun teklifi 6 Aralık 1940 tarihli oturumda TBMM Başkanlığı tarafından Milli Müdafaa, Maliye ve Bütçe encümenlerine havale edildi. ${ }^{77}$ Teklif 30 Aralık 1942 tarihli oturumda komisyon mazbataları ile birlikte genel kurul gündemine geldi. Maliye Komisyonu Başkanı İstanbul milletvekili Atıf Bayındır'ın talebi üzerine genel kurulda öncelikli olarak müzakere edilen teklif komisyon üyelerinin açıklamaları sonrasında yapılan oylamada genel kurul tarafından kabul edilerek yasalaştırıldı. ${ }^{78}$

Malatya milletvekili Mahmut Nedim Zabcı'nın iki milletvekili ile birlikte hazırladığı Inhisar beyiyeleri üçte birlerinin harp malûllerine ve şehit yetimlerine tahsis ve tevzii hakkındaki 1485 sayll kanunun 4'üncü maddesine bir fikra eklenmesine dair kanun teklifi parlamentonun 15 Haziran 1942 tarihli oturumunda Milli Müdafaa, Gümrük ve İnhisarlar, Maliye ve Bütçe encümenlerine havale edildi. ${ }^{79} 15$ Ocak 1943 tarihli oturumda Bütçe Encümeni mazbata muharriri Muğla milletvekili Hüsnü Kitapçı'nın öncelikli olarak görüşülmesine yönelik talebinin genel kurul tarafından kabul edilmesi üzerine müzakerelerine başlanan teklif üzerinde herhangi bir tartışma olmadan kabul edildi. ${ }^{80}$

\section{Yedinci Meclis Dönemi Faaliyetleri (1943-1946)}

1943 yılında toplanan yedinci meclis döneminde tek dereceli seçim sistemi kabul edildi. Liste usulü çoğunluk ilkesinin öngörüldüğü bu sistemde açık oy kapalı sayım sistemi kabul edildi

\footnotetext{
$74 T B M M Z C$, D. VI - C. 1, s. 19; TBMM ZC, D. VI - C. 6, s. 13; TBMM ZC, D. VI - C. 14, s. 15; TBMM ZC, D. VI - C. 21, s. 15 ; TBMM ZC, D. VI - C. 28, s. 10-11.

75 TBMM ZC, D. VI - C. 15, s. 194.

76 TBMM ZC, D. VI - C. 19, s. 2.

77 TBMM ZC, D. VI - C. 15, s. 18.

78 TBMM ZC, D. VI - C. 29, s. 242-245.

79 TBMM ZC, D. VI - C. 26, s. 178.

80 TBMM ZC, D. VI - C. 30, s. 279-280.
} 
ve 1946 yılında Türk parlamento tarihinde ilk defa tek dereceli seçimler yapıld1. ${ }^{81}$ Bu seçimlere CHP'nin yanında 1945 yılında kurulan Milli Kalkınma Partisi ile birlikte 7 Ocak 1946 tarihinde Celal Bayar, Adnan Menderes, Refik Koraltan ve Fuat Köprülü tarafından kurulan Demokrat Parti de katıldı. CHP seçimlerden tek başına iktidar olarak çıkarken, DP iktidarın hile ve yolsuzluklar yaptığını savundu. ${ }^{82}$

Mahmut Nedim Zabc1 yedinci dönem boyunca Maliye komisyonunda görev yapt $1{ }^{83}$ Dönem boyunca Meclis Başkanlı̆̆ı'na tek bir önerge sundu. Muamele Vergisi Kanunu'nun 10'uncu maddesinin 5 'inci fikrasının tefsirine dair verdiği önerge 19 Nisan 1944 tarihli oturumda Maliye, Bütçe, Adliye, İktisat, Ticaret, Gümrük ve İnhisarlar encümenlerine sevk edildi. ${ }^{84}$ Ancak Zabc1 3 Mayıs 1944 tarihinde meclis başkanlığından söz konusu önergesinin geri verilmesini talep etti. 5 Mayıs 1944 tarihli oturumda TBMM Başkanvekili Refet Canıtez Zabcı'nın önergesinin iade edildiğini genel kurula bildirdi. ${ }^{85}$

Mahmut Nedim Zabcı'nın yedinci dönem yasama süreci içerisinde imza attığı kanun teklifleri ise şunlard1:

Mahmut Nedim Zabcı'nın öncülügünde hazırlanan Fevkalâde vaziyet dolayısıyla bazı vergi ve resimlere zam icrasına dair olan 3828 numaralı kanuna ek 4040 sayıl kanunun 6 'ncl maddesinin değiştirilmesine dair kanun teklifi 5 Mayıs 1944 tarihli oturumda İktisat, Maliye ve Bütçe encümenlerine havale edildi. ${ }^{86} 8$ Ocak 1945 tarihinde meclis gündemine sevk edilen ${ }^{87}$ teklifin ilk müzakeresi 12 Ocak 1945 günü yapıldı. Malatya milletvekilleri Mahmut Nedim Zabcı, Kemal Sayın, Halet Sağıroğlu, Osman Hilmi Taner, Emrullah Barkan ve Memet Şevket Özpazarbaşı hazırladıkları kanun teklifinin gerekçesinde görüşlerini şöyle açıklıyorlardı: "Bulgur, döğme ve saire gibi bilhassa köylünün en mühim iaşe maddeleri şimdiye kadar vergiye tâbi tutulmamıştır. 4040 numaralı kanunun mucip sebepleri arasında da bulgur ve emsalinden vergi alınacağına dair bir kayıt ve sarahat yoktur. Değiştirilmesi bahis mevzuu olan 6’ncı maddede (Undan maada) tâbirinin tefsiriyle bulgur ve emsalinin vergiden istisna edilmesi arz ve teklif edilmiş ve bu tefsirin ilk müzakeresi yapılan İktisat encümeninde de bu gibi maddelerin vergiye tâbi olmalarının doğru olmayacă̆ı tezahür etmişse de (Undan maada) tâbirine bulgur ve emsalinin ithaline maddenin sarahati karşısında imkân görülememiştir. Bu sebeplerden dolayı bu kanuni teklifin yapılması zarureti hâsıl olmuştur"

81 Kenan Olgun, “Türkiye'de Cumhuriyetin İlanından 1950'ye Genel Seçim Uygulamaları”, Atatürk Araştırma Merkezi Dergisi, C. XXVII, S. 79, 2011, s. 22.

82 Cemil Koçak, Türkiye'de Milli Şef Dönemi (1938-1945), C. 1, İletişim Yayınları, İstanbul, 2012, s. 513532; Erol Tuncer, 1946 Seçimleri, TESAV Yayınları, Ankara, 2008, s. 123-128; Kemal H. Karpat, Türk Demokrasi Tarihi Sosyal, Ekonomik, Kültürel Temeller, Afa Yayınları, İstanbul, 1996, s. 143-144; Çetin Yetkin, Karşıdevrim 1945-1950, Yeniden Anadolu ve Rumeli Müdafaa-i Hukuk Yayınları, İstanbul, 2006, s. 289-293.

$83 T B M M$ ZC, D. VII - C. 1, s. 18; TBMM ZC, D. VII - C. 6, s. 11; TBMM ZC, D. VII - C. 14, s. 15; TBMM $Z C$, D. VII - C. 20, s. 17.

$84 T$ TBMM ZC, D. VII - C. 9, s. 62.

$85 T B M M Z C$, D. VII - C. 10, s. 4.

$86 T$ TBMM ZC, D. VII - C. 10, s. 4.

87 TBMM ZC, D. VII - C. 15, s. 24. 
Komisyonların yaptığı çeşitli değişiklikler sonucunda son şeklini alan kanun teklifi ilk müzakeresinde herhangi bir tartışma olmaksızın kabul edildi. ${ }^{8}$ İkinci müzakere ise 17 Ocak 1945 tarihinde gerçekleştirildi. Teklifin geneli üzerine yapılan açık oylama sonucunda 325 oy ve ittifakla Malatya milletvekillerinin kanun teklifi kabul edilerek yasalaştı. ${ }^{89}$

Malatya milletvekili Mahmut Nedim Zabcı'nın öncülüğünde dört milletvekilinin hazırladığı Askeri ve Mülki Tekaüt Kanunu'nun 16, 45 ve 58'inci maddelerine birer fikra eklenmesine dair kanun teklifi ise parlamentonun 5 Haziran 1945 tarihli oturumunda Milli Savunma, Maliye ve Bütçe encümenlerine havale edildi. ${ }^{90}$ Ancak Zabcı ve arkadaşları 16 Ocak 1946 tarihli oturumda meclis başkanlığına sundukları önerge ile ilgili kanun tekliflerinin geri verilmesini talep ettiler. Bunun üzerine teklif TBMM Başkanvekili Şemsettin Günaltay tarafından iade edildi. ${ }^{91}$

\section{Sekizinci Meclis Dönemi Faaliyetleri (1946-1950)}

Sekizinci dönem TBMM'ye DP'nin ana muhalefet partisi olarak katılması ile birlikte Türkiye'de çok partili siyasi hayata geçiş süreci başlamış oldu. Bu dönem içinde mecliste gittikçe sertleşen iktidar muhalefet ilişkilerine Cumhurbaşkanı İsmet İnönü müdahale ederek çok partili sistemin kurulmasına önemli katkılar yaptı. Özellikle 12 Temmuz 1947 tarihinde İnönü bir beyanname yayınlayarak iktidar ile muhalefete eşit mesafede durduğunu belirterek partileri uzlaştırmaya çalıştı. ${ }^{92}$

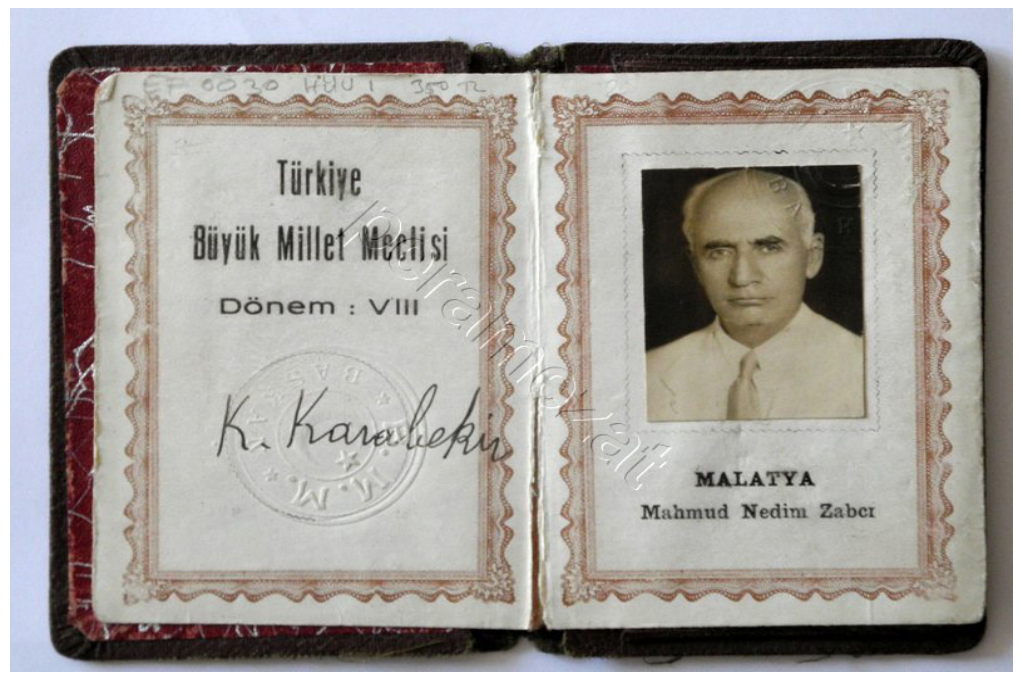

Mahmut Nedim ZABCI'nın TBMM Sekizinci Dönem Üye Kartı

(Kaynak: https://www.biyografya.com/biyografi/21588)

\footnotetext{
$88 T$ TBMM ZC, D. VII - C. 15, s. 72.

89 TBMM ZC, D. VII - C. 15, s. 111-113.

90 Türkiye Büyük Millet Meclisi Tutanak Dergisi (TBMM TD), D. VII - C. 18, s. 114.

91 TBMM TD, D. VII - C. 21, s. 50.

92 Taner Timur, Türkiye’de Çok Partili Hayata Geçiş, İmge Kitabevi, Ankara, 2003, s. 78.
} 
Mahmut Nedim Zabcı sekizinci dönem boyunca Maliye komisyonunda görev yapt1. ${ }^{93}$ Zabcı'nın dönem boyunca imza attığı kanun teklifleri ise şunlardı:

CHP Yozgat milletvekili Sırrı İçöz'ün öncülüğünde Malatya milletvekili Mahmut Nedim Zabc1, Sivas milletvekili Şemsettin Günaltay ve Niğde milletvekili Halit Mengi'nin hazırladı̆̆ Temsil Heyeti Üyeleriyle Birinci Büyük Millet Meclisi Üyelerine vatani hizmet karşılı̆̆ ödenek verilmesi hakkında kanun teklifi 2 Mayıs 1947 tarihinde TBMM Başkanlığı'na sunuldu. Teklifin gerekçesinde “İstanbul Hükümeti'nin işgal altında düşmanların her arzularına ramolduğu bir sırada Millî Türk Hükümeti'nin ilk nüvesini teşkil eden Heyeti Temsiliye âzası bütün sorumluluğu üzerine alarak faaliyete başladığl ve sonra da Ankara'da toplanan Birinci Büyük Millet Meclisi'nin millî bir Hükümet kurarak İstiklâl Harbi'ni zaferle sona erdikten sonra da Doğu'da ve Batı'da anlaşmalar yaparak Millî Hükümet'in istiklâlini temin ettiği malûmdur. Bütün sorumlulukları üzerlerine alan bu fedakâr Türk çocukları bugün yaşlanmışlardır, çoğu da zaruret içindedirler; bunlara Cumhuriyet Hükümetimizin yardım elini uzatması tarihimize karşı olduğu kadar da milletimize karşı şerefli bir ödevdir. Bunun için bağlı altı maddelik kanun tasarısı hazırlanmış ve Büyük Millet Meclisi'nin yüksek katına sunulmuştur” deniliyordu.

Maliye ve Bütçe komisyonları tarafindan incelenip kabul edilen söz konusu kanun teklifi komisyonların üzerinde yaptığı birtakım değişikliklerden sonra son halini alarak 20 Şubat 1948 tarihli oturumda müzakere edildi. Komisyonların ivedilikle görüşülmesini istediği kanun teklifinin temel maddeleri şöyleydi:

“MADDE 1. Sivas Temsil Heyeti üyeleriyle Birinci Büyük Millet Meclisi üyelerinden bu kanunun yürürlüğe girdiği tarihte să̆ bulunanlara yaşadıklarl müddetçe ödenmek ve başkaca zam yapılmamak kaydıyla vatani hizmet tertibinden 350 'şer lira aylık bağlanmıştır.

MADDE 2. Birinci maddede yazılı olanlardan ölmüş bulunanların bu kanunun yürürlüğe girdiği tarihte să̆ bulunan;

a) Evlenmemiş karısına,

b) Yirmi yaşıına girmemiş, yüksek tahsile devam etmekte ise, yirmi beş yaşııı geçmemiş erkek çocuklarına,

c) Evlenmemiş ve yaşları da yirmi beşi doldurmamış kız çocuklarına,

Vatani hizmet tertibinden 175 lira aylık verilir Bu madde gereğince ayliğa müstahak olanlar birden fazla ise bu miktar aralarında müsavi olarak taksim olunur.

MADDE 3. Sivas Temsil Heyeti ile Birinci Büyük Millet Meclisine üye seçildiği halde iltihak etmeyenlerle iltihakettikten sonraçekilenler, mazbatası kabuledilmeyenler, iskat edilenler veya daimî bir memuriyeti tercih ederek ilgisini kesenler ve bunların ikinci maddede yazll dul ve yetimleri bu kanun hükümlerinden faydalanamazlar"

Birçok milletvekilinin söz aldığı ve maddeler üzerinde çok sayıda değişiklik önergesinin verildiği müzakereler sürerken Bütçe komisyonu sözcüsü Ankara milletvekili Muammer Eriş kabul edilen maddelerin esaslı bir şekilde yazılması için kanun teklifinin komisyona iade edilmesini istedi.

$93 T$ TBMM TD, D. VIII - C. 1, s. 22; TBMM TD, D. VIII - C. 2, s. 13; TBMM TD, D. VIII - C. 7, s. 14; TBMM $T D$, D. VIII - C. 13, s. 23; TBMM TD, D. VIII - C. 21, s. 23. 
Bunun üzerine TBMM Başkanı Ali Fuat Cebesoy teklifin komisyona geri verildiğini bildirdi. ${ }^{94}$ Komisyonun yaptığı yeni düzenlemelerin ardından 10 Mayıs 1948 tarihinde tekrar müzakereler başladı ancak yeni değişiklik önergeleri kanun teklifinin tekrar komisyona verilmesi sonucunu doğurdu. ${ }^{95} 25$ Haziran 1948 tarihli oturumda yeniden başlayan görüşmelerde ise kanun teklifinin isimler üzerinden hazırlanmak üzere komisyona havale edilmesi kararı çıktı. ${ }^{96}$ Ancak teklif uzunca bir süre komisyonda kalınca Zabcı ve arkadaşları 10 Aralık 1948 tarihli önerge ile TBMM içtüzüğü gereği komisyona gönderilen kanun tasarı ve tekliflerinin maksimum bir buçuk ay içerisinde meclise gönderilmesi gerektiğini belirterek kanun tekliflerinin gündeme alınmasını talep ettiler. Bunun üzerine komisyon sözcüsü Muammer Eriş komisyonun bütçe incelemeleri nedeniyle yoğun olduğunu belirterek bütçe görüşmelerinin ardından söz konusu kanun teklifinin ele alınacağını ifade etti. Genel kurulda yapılan oylama sonucunda önerge kabul edilerek ilgili kanun teklifinin gündeme alınması kararlaştırıldı. ${ }^{97} 15$ Aralık 1948 tarihli oturumda kanun teklifinin müzakerelerine devam edildi. Yapılan son düzenlemelerin ardından kanun teklifi 246 kabul, 6 red ve 1 çekimser oyla kabul edilerek uzun bir müzakere süreci sonunda yasalaşmış oldu. ${ }^{98}$

Mahmut Nedim Zabcı'nın bu yasama yılında verdiği kanun tekliflerinden bir diğeri de Konya milletvekili Fatin Gökmen ile birlikte hazırladı̆̆ı Yüksek Jeodezi Enstitüsü ve memleket umum harita işleri hakkında kanun teklifi idi. Söz konusu teklif parlamentonun 11 Haziran 1948 tarihli oturumunda Milli Eğitim, Milli Savunma, Bayındırlık, İçişleri ve Bütçe komisyonlarına sevk edildi. ${ }^{99}$

Mahmut Nedim Zabcı'nın hazırladığı Ticaret Kanunu'nun 502'nci maddesine bazı fikralar eklenmesine dair kanun teklifi meclisin 28 Aralık 1949 tarihli oturumunda Adalet Komisyonu'na havale edildi. ${ }^{100}$ Ancak Zabcı 24 Şubat 1950 tarihli bir önerge ile söz konusu kanun teklifini geri aldığını belirtti. Bu durum üzerine TBMM Başkanvekili Cevdet Kerim İncedayı önergenin iade edildiğini genel kurula bildirdi. ${ }^{101}$

Mahmut Nedim Zabcı'nın hazırladı̆̆ı bir diğer kanun teklifi ise Tarım Satış Kooperatifleri ve Birlikleri hakkındaki kanunun 21 'inci maddesine bir fikra eklenmesine dair kanun teklifi idi. Bu teklif ise meclisin 24 Şubat 1950 tarihli oturumunda Tarım ve Bütçe komisyonlarına sevk edildi. ${ }^{102}$

\section{Sonuç}

Erken Cumhuriyet döneminde parlamentoda görev yapan milletvekilleri yoğun olarak askeri ve sivil bürokrasi ile yerel eşrafa dayanıyordu. Milli Mücadele'ye destek veren bu kesimler yeni devletin oluşum sürecinin de temel aktörleri oldular. 1923-1950 yılları arası mecliste görev yapan Mahmut Nedim Zabcı da askeri bürokrasiden gelen bir isimdi. TBMM'de 27 y1l aralıksız devam

$\begin{array}{ll}94 & T B M M T D, \text { D. VIII - C. } 10, \text { s. 278-306. } \\ 95 & T B M M T D, \text { D. VIII - C. } 11, \text { s. 293-302. } \\ 96 & T B M M T D, \text { D. VIII - C. } 11, \text { s. 366-372. } \\ 97 & T B M M T D, \text { D. VIII - C. } 14, \text { s. } 87-92 . \\ 98 & T B M M T D, \text { D. VIII - C. } 14, \text { s. } 122-135 . \\ 99 & T B M M T D, \text { D. VIII - C. } 12, \text { s. } 152 . \\ 100 & T B M M T D, \text { D. VIII - C. } 22, \text { s. } 519 . \\ 101 & T B M M T D, \text { D. VIII - C. } 24, \text { s. } 1141 . \\ 102 & T B M M T D, \text { D. VIII - C. } 24, \text { s. } 1140 .\end{array}$


eden milletvekilliği süresince Malatya'yı temsil etti. Türkiye Cumhuriyeti Devleti'nin temellerinin atıldığı ve kurumsal yapısının oluş̧urulduğu yıllarda TBMM'de görev yapan Mahmut Nedim Bey böylece Atatürk inkılaplarının yasal statü kazandırılarak hayata geçirilmesi sürecinin içinde yer aldı. Bu uzun parlamenterlik deneyimi Zabcı'yı TBMM tarihinde İsmet İnönü'den sonra en uzun süre Malatya milletvekilliği yapan isim haline de getirdi.

Mahmut Nedim Zabcı TBMM'de yedi dönem görev yaptı. Bu dönemler içinde yasama çalışmalarına en aktif katılım gösterdiği süreç ikinci dönem oldu. Cumhuriyetin ilk dört yılını oluşturan bu yasama döneminde genel kurulda altı defa söz alan Zabcı, aynı zamanda on altı önergenin ve beş kanun teklifinin altına imza attı. Aynı zamanda bazı sosyal inkılapların hazırlanması ve meclis genel kurulunda yasalaşması süreçlerine komisyon düzeyinde direkt katkı sundu. Zabcı'nın bu kriterler göz önüne alındığında en pasif olduğu yasama dönemi TBMM'nin beşinci dönemi oldu. Zira 1935-1939 yıllarını kapsayan bu dönemde Mahmut Nedim Bey genel kurulda hiç söz almadığı gibi önerge, kanun teklifi vb. yasama ve denetim faaliyetleri içerisinde bulunmadı. Bu durumun oluşmasında tek parti rejiminin ilgili yıllarda tamamen yerleşmesinin yarattığı etki önemli bir neden olarak düşünülebilir. Zira söz konusu dönem parti-devlet bütünleşmesinin resmileşme dönemi olarak dikkat çekmektedir. Zabcı'nın uzun yıllar süren parlamento yaşamı boyunca dikkat çeken bir husus da hiç soru önergesi vermemiş olması idi. Ayrıca 27 yıllık milletvekilliği süresince farklı dönemlerde olmak üzere toplam beş ay izin kullandı. Diğer yandan Zabcı'nın yasama faaliyetleri dönemsel olarak diğer Malatya milletvekilleri ile kıyaslandığında ikinci ve üçüncü meclis dönemlerinde en fazla önerge veren Malatya milletvekili, dördüncü ve sekizinci meclis dönemlerinde en fazla kanun teklifi veren Malatya milletvekili, altıncı meclis döneminde dönem boyunca önerge ve kanun teklifi veren tek Malatya milletvekili, yedinci meclis döneminde en fazla önerge ile kanun teklifi veren Malatya milletvekili olduğu görülmektedir.

Milletvekilliği boyunca seçim bölgesi ve memleketi Malatya'nın sorunlarını da meclis gündemine taşımaya ve çözüm yolları aramaya gayret eden Zabcı bu doğrultuda Meclis Başkanlığına çok sayıda önerge verdi. Meclis içinde olduğu kadar dışında da Malatya'nın sorunları ile yakından ilgilenen ve özellikle eğitime büyük önem veren Zabcı Ankara ve İstanbul'da okuyan Malatyalı üniversite öğrencilerinin başta yurt olmak üzere temel sorunlarının çözümü noktasında önemli hizmetler gerçekleştirdi. Okumuşu Çoğaltma ve Okuyanı Koruma Cemiyeti bünyesinde sürdürdüğu eğitim faaliyetleri bu bağlamda son derece önemli sonuçlar doğurdu. Öyle ki Ankara ve İstanbul'da okuyan Malatyalı üniversite öğrencileri 28 Mart 1950 tarihinde Yüksek Tahsilde Bulunan Malatyalı Gençlerin Hemşehrilerine Beyannamesi başlıklı bir beyanname yayınladılar. Malatya halkından yaklaşan seçimlerde oylarını Mahmut Nedim Zabcı'ya vermelerinin istendiği dört sayfalık beyannamede Zabcı'nın 27 yıllık milletvekilliği süresince Malatya'ya yaptığı hizmetler maddeler halinde sıralanmıştı. ${ }^{103}$

Zabcı'nın Malatya milletvekili olarak çeyrek asrı geçen uzun bir siyasi kariyere sahip olmasında seçim bölgesine yönelik hizmetleri ve halktan gördüğü karşıllğın yanı sıra Milli Mücadele’nin ve Cumhuriyetin kurumsallaşma sürecinin ana aktörü olan askeri bürokrasiye mensup olması temel etkendir. Bu iki nokta ile birlikte Atatürk inkılaplarına olan bağl1lı̆̆ Mahmut Nedim Bey'in tek parti döneminde CHP Başkanlık Divanı tarafından milletvekili adayı olarak tercih edilmesinde kuşkusuz önemli bir yer tutar. 


\section{Kaynakça}

\section{Arşivler}

\section{T.C. Cumhurbaşkanlığı Devlet Arşivleri Başkanlığı Cumhuriyet Arşivi}

- Başbakanlık Muamelat Genel Müdürlüğü Katalogu

Fon Kodu 30.10 Yer No 6.36.27

Fon Kodu 30.10 Yer No 6.36.15

Fon Kodu 30.10 Yer No 7.40.12

Fon Kodu 30.10 Yer No 3.18.16

- Cumhuriyet Halk Partisi Katalogu

Fon Kodu 490.01 Yer No 312.1274.1

Fon Kodu 490.01 Yer No 235.929.4

Fon Kodu 490.01 Yer No 374.1576.2

\section{Türkiye Büyük Millet Meclisi Arşivi}

Mahmut Nedim Zabcı'ya ait mazbatalar ve tercüme-i hâl kâğıtları (Sicil No 584)

\section{Emekli Sandığı Genel Müdürlüğü Arşivi}

Mahmut Nedim Zabc1 dosyası (Dosya No A0109668)

\section{Resmi Yayınlar}

TBMM Zabıt Ceridesi, Dönem II, C. 1-33.

TBMM Zabıt Ceridesi, Dönem III, C. 1-26.

TBMM Zabıt Ceridesi, Dönem IV, C. 1-25.

TBMM Zabıt Ceridesi, Dönem V, C. 1-29.

TBMM Zabıt Ceridesi, Dönem VI, C. 1-30.

TBMM Zabıt Ceridesi, Dönem VII, C. 1-16.

TBMM Tutanak Dergisi, Dönem VII, C. 16-24.

TBMM Tutanak Dergisi, Dönem VIII, C. 1-25.

TBMM Gizli Celse Zabıtları, Dönem II, C. 8/1. 


\section{Araştırma İnceleme Eserleri}

Akandere, Osman, Millî Şef Dönemi Çok-Partili Hayata Geçişte Rol Oynayan İç ve Dlş Tesirler 1938-1945, İz Yayıncılık, İstanbul, 1998.

Avc1, Cemal, III. Dönem Türkiye Büyük Millet Meclisi'nin Yapısı ve Faaliyetleri (19271931), Atatürk Araştırma Merkezi Yayınları, Ankara, 2000.

Çavdar, Tevfik, "Serbest Fırka", Cumhuriyet Dönemi Türkiye Ansiklopedisi, C. 8, İstanbul, 1983.

Demirel, Ahmet, Tek Partinin İktidarı Türkiye'de Seçimler ve Siyaset (1923-1946), İletişim Yayınları, İstanbul, 2013.

Dursun, Tuncay, Tek Parti Dönemindeki Cumhuriyet Halk Partisi Büyük Kurultayları, Kültür Bakanlığı Yayınları, Ankara, 2002.

Kabasakal, Mehmet, Türkiye'de Siyasal Parti Örgütlenmesi 1908-1960, Tekin Yayınevi, İstanbul, 1991.

Karpat, Kemal H., Türk Demokrasi Tarihi Sosyal, Ekonomik, Kültürel Temeller, Afa Yayınları, İstanbul, 1996.

Kili, Suna / Şeref Gözübüyük, Sened-i Ittifak’tan Günümüze Türk Anayasa Metinleri, Türkiye İş Bankası Kültür Yayınları, İstanbul, 2006.

Koçak, Cemil, Türkiye'de İki Partili Siyasî Sistemin Kuruluş Yılları (1945-1950) İkinci Parti, C. 1, İletişim Yayınları, İstanbul, 2010.

Koçak, Cemil, Türkiye'de Milli Şef Dönemi (1938-1945), C. 1, İletişim Yayınları, İstanbul, 2012.

Olgun, Kenan, “Türkiye'de Cumhuriyetin İlanından 1950'ye Genel Seçim Uygulamaları”, Atatürk Araştırma Merkezi Dergisi, C. XXVII, S. 79, 2011, s. 1-35.

Öz, Esat, Otoriterizm ve Siyaset Türkiye'de Tek-Parti Rejimi ve Siyasal Katılma (1923-1945), Yetkin Yayınları, Ankara, 1996.

Öztürk, Kazım, Türk Parlamento Tarihi (TBMM II. Dönem 1923-1927), C. 3, TBMM Vakf1 Yayınları, Ankara, 1995.

Pekdoğan, Celal, Milli Mücadelede Malatya ve Çevresi (Demografik, İdarî, Siyasi ve SosyoEkonomik Açıdan) 1918-1922, Hacettepe Üniversitesi Atatürk İlkeleri ve İnkılâp Tarihi Enstitüsü (Yayınlanmamış Yüksek Lisans Tezi), Ankara, 1992.

Sezgin, Ömür / Gencay Şaylan, "Terakkiperver Cumhuriyet Furkası”, Cumhuriyet Dönemi Türkiye Ansiklopedisi, C. 8, İstanbul, 1983.

Şahin, Mehmet Serkan, Türkiye Büyük Millet Meclisi’nde Malatya Milletvekilleri ve Siyasi Faaliyetleri (1923-1950), Kahramanmaraş Sütçü İmam Üniversitesi Sosyal Bilimler Enstitüsü, (Yayınlanmamış Doktora Tezi), Kahramanmaraş, 2016.

Timur, Taner, Türkiye'de Çok Partili Hayata Geçiş, İmge Kitabevi, Ankara, 2003.

Tunaya, Tarı Zafer, Türkiye'de Siyasi Partiler 1859-1952, İstanbul, 1952. 
Tuncer, Erol, 1946 Seçimleri, TESAV Yayınları, Ankara, 2008.

Tunçay, Mete, "Cumhuriyet Halk Partisi (1923-1950)", Cumhuriyet Dönemi Türkiye Ansiklopedisi, C. 8, İstanbul, 1983.

Uran, Hilmi, Hatıralarım, Ankara, 1959.

Uyar, Hakk1, Tek Parti Dönemi ve Cumhuriyet Halk Partisi, Boyut Kitapları, İstanbul, 1999.

Yetkin, Çetin, Karşıdevrim 1945-1950, Yeniden Anadolu ve Rumeli Müdafaa-i Hukuk Yayınları, İstanbul, 2006.

Yükseliman, Nihan, Parti Devlet Bütünleşmesi, Gelenek Yayınları, İstanbul, 2002. 